2012

\title{
Food Safety and Risk Governance in Globalized Markets
}

Sandra Hoffmann

William Harder

Follow this and additional works at: https://scholarlycommons.law.case.edu/healthmatrix

Part of the Health Law and Policy Commons

\section{Recommended Citation}

Sandra Hoffmann and William Harder, Food Safety and Risk Governance in Globalized Markets, 20 Health Matrix 5 (2010) Available at: https://scholarlycommons.law.case.edu/healthmatrix/vol20/iss1/4

This Symposium is brought to you for free and open access by the Student Journals at Case Western Reserve University School of Law Scholarly Commons. It has been accepted for inclusion in Health Matrix: The Journal of Law-Medicine by an authorized administrator of Case Western Reserve University School of Law Scholarly Commons. 


\title{
FOOD SAFETY AND RISK GOVERNANCE IN GLOBALIZED MARKETS
}

\author{
Sandra Hoffmann and William Harder ${ }^{\dagger}$
}

\section{INTRODUCTION}

Modern food safety policy came into being at the turn of the twentieth century in response to scandals in the meat-packing and food-processing industries. ${ }^{1}$ Behind these scandals lay dramatic changes in the economic structure of food production and distribution. Rapid technological change was transforming life into something now recognizable as a modern urban-industrial society. Food production was shifting away from home or local production and processing toward more industrial processing and regional or even national marketing. In the United States, long-distance rail systems and refrigerated

† Sandra Hoffmann is a Fellow with Resources for the Future. William Harder is a Ph.D. student in Political Science and Public Administration at American University. We thank Richard Williams (George Mason University) for sharing insights from his experience with food safety risk analysis and economics at U.S. FDA.

${ }^{1}$ The 1906 Neil-Reynolds report to Congress documents conditions of filth and lack of sanitation in Chicago stockyards. Among the many unsanitary conditions, they found workers urinating in the slaughter hall because privies were too far away, unsanitary privies in areas used for butchering, lack of soap and water for workers, and meat piled on slimy wooden floors shoveled onto rotting wooden tables for butchering. Conditions in Chicago Stockyards: Message from the President of the United States Before the Comm. on Agric., 59th Cong. (1st Sess. 1906) (transmitting the Report of Mr. James Bronson Reynolds and Commissioner Charles P. Neill, Special Committee Appointed to Investigate the Conditions in the Stock Yards of Chicago). Fraud and adulteration of nonmeat foods was also common. A noted food authority of the time described some of the ways foods were adulterated. Edward A. Ayers, What the Food Law Saves Us From: Adulterations, Substitutions, Chemical Dyes, and Other Evils, in 14 THE WORLD's WORK: A HISTORY OF OUR TIME 9316, 9319 (1910). Milk was watered and then made to look heavier in fat content with cheaper coloring and caramel. Formaldehyde (a carcinogen) was used to conceal fermentation. Jellies labeled "pure" were often glucose, artificially flavored and "jelled" with gelatin rather than fruit jelled with natural pectin as implied by the label "pure." For a historical perspective on economic and social situations leading to food safety legislation in the United States in 1906, see generally UPTON SinCLAIR, THE JUNGLE (Viking Press 1950) (1906). 
railcars made possible the rise of a national meat-packing industry, with primary production across the Great Plains and slaughter and processing in rail centers such as Kansas City and Chicago. Institutions that had emerged to manage safety risks associated with local production and distribution were incapable of safeguarding health in this more nationally integrated economy. Substantial institutional innovation was needed to manage the resulting changes in health risks. In 1906, the U.S. Congress passed both the Meat Inspection Act of $1906^{2}$ and the Pure Food and Drug Act. ${ }^{3}$ In amended form, this legislation remains the core of U.S. food safety law. ${ }^{4}$

A new generation of major food safety policy reform is now emerging. These reforms are also being driven by scandals and crises of trust: among them, the Jack in the Box E. coli outbreak in the United States that sickened more than 600 and killed four children in January 1993; the bovine spongiform encephalopathy (BSE) crises in Britain and Europe; dioxin contamination of Belgian livestock feed; and adulteration of Chinese food exports with melamine. ${ }^{5}$ As at the start of the twentieth century, economic and technological transformations in both food and the food supply system lie behind these more recent food safety crises. The past three decades have seen both heightened concentration among food production and marketing firms and the globalization of food supply chains. Global revolutions in information and transportation technology have enabled these changes. Rapid advances in life and materials sciences are giving rise to novel products and practices whose safety remains unproven in many consumers' eyes. Governments are struggling to create institutions that can address the implications these changes have for public health.

At the heart of this new generation of food safety reform is a growing international consensus on the need for risk-based, scientifically supported policies that prevent food contamination and food-

\footnotetext{
${ }^{2}$ Federal Meat Inspection Act of 1906, 34 Stat. 674.

${ }^{3}$ Pure Food and Drugs Act of 1906, 34 Stat. 768.

${ }^{4}$ See 21 U.S.C. $\$ \S 601-625$ (meat inspection); Federal Food, Drug and Cosmetic Act, 21 U.S.C. $\$ 301$.

${ }^{5}$ Elise Golan ET al., U.S. DeP'T OF Agric., Food Safety InNovation in THE UNITEd States: EvidenCE From the MEAT IndUSTRy, Agric. ECON. REPORT No. 831, at 10 (2004), available at http://www.ers.usda.gov/publications/aer831/; BBC News, BSE and CJD: Crisis Chronology, http://news.bbc.co.uk/hi/english/static/in depth/health $/ 2000 / \mathrm{bse} /$ default.stm (last visited May 3, 2010); Ahmed ElAmin, Belgium, Netherlands Meat Sectors Face Dioxin Crisis (Jan. 31, 2006), http://www .foodproductiondaily.com/Quality-Safety/Belgium-Netherlands-meat-sectors-face-di oxin-crisis; Melamine Found in Chinese-Made Food Products, N.Y. Times, Sept. 26, 2008, http://www.nytimes.com/2008/09/26/world/asia/26iht-milk.4.16516560.html.
} 
borne illness through integrated risk management from farm-to-table. ${ }^{6}$ As will be discussed, these policies likely will differ from country to country, but they are being guided by a shared set of principles that have emerged through several decades of discussion and collaborative technical work at the national and international levels in both the public and private sectors. ${ }^{7}$ Policy reform proposals are being shaped by worldwide trends toward greater global economic integration, increased reliance on the use of decision and risk analysis in public administration, and the spread of total quality management practices in private industry.

Risk analysis, a set of systematic methods for assessing and managing hazards, provides the core intellectual framework for this food safety reform movement. The practices of risk analysis in public administration have been developed and formalized since the early 1980s to address a diverse range of hazards, from environmental toxins to nuclear power generation to safety in space flights. As discussed below, risk analysis is conventionally viewed as involving both the scientific assessment and management of risks.

The central theme of this article is that global coordination of food safety policy and management is absolutely essential to providing a safe food supply in an increasingly globalized economy. No country by itself can ensure the safety of its population's food supply in this modern economy. Yet at the same time, there is intense concern about maintaining national sovereignty, particularly because in areas like food and health risk, there are strong cultural differences across countries. With United Nations facilitation, a structure for collaborative international technical deliberation has evolved that is providing a mechanism for food safety policy coordination across countries. This effort appears to be reasonably successful and may provide a model of how global coordination of legal institutions could occur in other policy arenas such as chemical regulation and climate change.

Global coordination of food safety management will necessarily involve not only collaboration among national governments, but also the efforts of private industries to ensure the safety of products along their international supply chains. Management of food safety in a

${ }^{6}$ One purpose of this article is to introduce readers to the process through which this consensus has emerged. For an example of the kinds of efforts involved, see World Health Org. [WHO], Assuring Food Safety and Quality: Guidelines for Strengthening National Food Control Systems, http://www.who.int/foodsafety/ publications/fs management/guidelines_foodcontrol/en/index.html (last visited May 3,2010 ) (providing guidance to national governments seeking to strengthen their food safety control systems).

7 See infra Section II. 
globalized economy requires reliance on both public and private controls. This new generation of food safety policy is rightly embodying efforts by the public sector to leverage and support private sector safety management.

Significant advantages flow from having a shared vision of the basic framework for food safety policy and management. From a trade law perspective, it enhances legal transparency and in so doing should help reduce trade disputes. But more important, from a safety perspective, it should increase the ability of national governments to ensure the safety of imports. Less obviously, having a shared vision of the structure of a modern food safety system is allowing government officials, industrial managers, food safety engineers, scientists, and economists in countries around the world, particularly in Organisation for Economic Co-operation and Development (OECD) countries, to build on each other's efforts. Scientists at the U.S. Centers for Disease Control (CDC) are learning lessons from Danish public health officials about foodborne disease surveillance. ${ }^{8}$ The work of U.S. Food and Drug Administration (FDA) scientists in developing methods of quantitatively modeling the way microbial hazards enter and spread in the food supply chain led the way for similar efforts in Europe and by the World Health Organization (WHO). ${ }^{9}$ WHO risk assessments in turn have provided U.S. officials and private sector food safety managers with a sounder scientific basis for U.S. food safety policy. Having a common vision of the elements and structure of this new generation of food safety policy also makes it possible to develop data and communication systems that can help identify the emergence of new hazards in the food supply as well as their sources and transmission, nationally and globally. ${ }^{10}$ To the extent that this shared vision results in a relatively consistent regulatory environment, it will also facilitate the development and spread of better safety management practices in production, processing, and distribution of food. These collaborative efforts should enhance the ability of both government and industry to ensure the safety of food produced domestically as well as imports.

${ }^{8}$ Elaine Scallan, Ctrs. for Disease Control \& Prevention, Attempting to Apply the Danish Food Attribution Model in the United States (Apr. 26, 2005), http://www.card.iastate.edu/food_safety/workshop3/presentations/10_danish_food .htm.

${ }^{9}$ For an early discussion of this work, see Robert Buchanan \& Bart Suhre, New Developments in Chemical and Microbial Risk Assessment, in TOWARD SAFER Food: Perspectives on Risk and Priority SetTing 10 (Sandra A. Hoffmann \& Michael R. Taylor eds., 2005).

${ }^{10}$ See infra text accompanying notes 160-168, 223. 
I also offer a note of caution. One of the dangers in all management systems, whether public or private, is that once policies are adopted, they are hard to change. ${ }^{11}$ This is a basic problem in domestic law and policy. Greater integration of policy internationally will increase the difficulty of reversing $b a d$ policies once locked in place. ${ }^{12}$ It also means that locking in bad policies and practices at the national level are likely to have impacts beyond national boundaries. A fundamental challenge for law and public administration in our increasingly integrated global economy will be to develop institutional structures and practices that prevent such lock-in by allowing evolution of international rules and norms while at the same time adequately protecting expectations.

We have already seen an example of this problem in the arena of food safety. An old adage among U.S. lawyers is that "bad facts make bad law." It takes a very cool head to think clearly in the face of

11 Path dependency of "lock-in" coupled with switching costs has been used to understand why inefficient or inferior technologies come to dominate markets. W. Brian Arthur, Competing Technologies, Increasing Returns, and Lock-In by Historical Events, 99 ECON. J. 106 (1989) (a seminal early paper); Joseph Farrell \& Paul Klemperer, Coordination and Lock-In: Competition with Switching Costs and Network Effects, in HANDBOOK OF INDUSTRIAL ORGANIZATION 3 (M. Armstrong \& R. Porter eds., 2007) (examining how switching costs prevents customers from shifting from one product to another, giving early innovators market power). This same paradigm has also been used to explain "stickiness" in policy evolution. David Wilsford, Path Dependency, or Why History Makes It Difficult but Not Impossible to Reform Health Care Systems in a Big Way, 14 J. PuB. PoL'Y 251 (1994) (using the concept of path dependency to examine the dynamics of policy change in health care). The difficulty the United States has had in consolidating food safety agencies or significantly reforming meat inspection can be seen as examples of policy "lock-in" where there is a high institutional and political cost to switching from one regime to another. For example, the 1906 Meat Inspection Act led to the emergence of a strong meat inspectors' union, which has been a vocal supporter for the current inspection system. See, e.g., Testimony of Stanley Painter, Chairman, Nat'l Joint Council of Food Inspection Local Unions, AFL-CIO, Before Domestic Policy Subcomm., H. Comm. on Oversight \& Gov't Reform (Apr. 17, 2008).

12 To some extent, national legal systems have developed mechanisms to allow the evolution of law, in response either to changed conditions or to changed understandings of what constitutes good policy. In the United States and former British Commonwealth, common law strikes a balance between ensuring stable expectations by reliance on precedence and providing a means of adjusting rules to changed circumstances. See JoHN R. COMMONS, LEGAL FOUNDATIONS OF CAPITALISM (Univ. Wis. Press 2006) (1924). Legislative bodies provide another mechanism for changing rules, though the fact that U.S. meat inspection is still governed by 1906 legislation points to the difficulty of changing major legislation. A challenge for jurisprudence in the coming decades will be developing mechanisms to allow this kind of adaptation in a world where national legal systems are more tightly integrated globally. 
"bad facts." The facts surrounding the BSE crisis in the United and continental Europe were horrific and had profound effects on the development of European food safety law reform. ${ }^{13}$ Major government investigations within the United Kingdom and by the European Union (EU) highlighted the role that the influence of commercial agricultural interests on government scientific analysis played in prolonging the BSE crisis and deepening its health impact. ${ }^{14}$

One impact of this finding has been the adoption of EU food safety law that rigidly separates risk assessment (scientific analysis of how risks arise) from risk management (decision-making about how best to reduce risks). In the process, economics and social sciences, which are commonly viewed solely as part of risk management rather than scientific analysis, have also been isolated from scientific assessment of risk. Yet food safety risks are created by human activities affecting biological and physical processes. Economics and other behavioral sciences provide a scientific basis for modeling and measuring behavioral influences on health risks. Isolation of economics and other behavioral science analysis from risk assessment could lead to less accurate risk assessment and a weaker scientific foundation for food safety risk management. With greater global integration, this policy has the potential to affect not only Europe, but other countries as well, including the United States.

This paper presents an overview of current food safety problems and the global risk governance structure that is emerging to manage these problems. Section I examines food safety as a public health and economic issue. Section II describes the development of risk analysis as a regulatory paradigm in the United States and Europe. Section III discusses globalization and the role of a risk analysis paradigm in the emerging global framework for this new generation of food safety policy. Section IV examines regional and national food safety reforms in response to crises at both of these levels of government and articulates how such reforms are being shaped by this global framework. The paper concludes with a brief discussion of the implications of this history for food safety reform in the United States.

\section{RECENT FOOD SAFETY TRENDS}

Food safety, particularly infectious foodborne illness, is a significant and increasing global health concern. ${ }^{15}$ Population-level food-

${ }^{13}$ See infra text accompanying notes $138-180$.

${ }^{14}$ See infra text accompanying notes $134,142-143$.

15 See J. Rocourt et al., WHO, The Present State of Foodborne Disease in OECD Countries (2003), available at http://www.who.int/foodsafety/publications/ 
borne disease incidence is quite uncertain as a result of significant underreporting. ${ }^{16}$ However, the CDC estimates that in the United States, approximately 76 million illnesses, 325,000 hospitalizations, and 5,000 deaths occur annually from foodborne infections. ${ }^{17}$ Incidence of foodborne illness is undoubtedly higher in developing countries, but the statistics are even more uncertain there, with fewer resources to devote to disease surveillance. ${ }^{18}$ The WHO estimates that each year, approximately 2.2 million people in developing countries die from foodborne and waterborne infectious disease. ${ }^{19}$ In addition to the direct suffering involved, the associated morbidity also drains productivity, imposing an in-kind tax on human energy. ${ }^{20}$

Over the last two to three decades, foodborne infectious disease has emerged as the primary health concern driving food safety policy. $^{21}$ New knowledge about the extent and severity of foodborne infectious disease has driven this focus. Epidemiological data from countries around the world showed substantial increases in the rate of foodborne infectious diseases from the 1970s into the 1990s. ${ }^{22}$ Public health scientists are confident that this was not simply the result of increased investment in disease surveillance, but represented a real increase in the incidence of foodborne illness. ${ }^{23}$ Scientists are also recognizing that foodborne illness may be more serious than previously thought. New pathogen hazards, such as BSE and shiga-toxinproducing $E$. coli, have recently emerged, causing serious health consequences including organ failure and death. ${ }^{24}$ And medical re-

foodborne_disease/oecd fbd.pdf; WHO, WHO Global Strategy for Food Safety: Safer Food for Better Health, at 1 (2002), available at http://www.who.int/foodsafety/ publications/general/en/strategy_en.pdf.

${ }^{16}$ Ctrs. for Disease Control \& Prevention, FoodNet Surveillance: Burden of Disease Pyramid, http://www.cdc.gov/foodnet/surveillance_pages/burden_pyramid .htm (last visited May 3, 2010).

17 Paul S. Mead et al., Food-Related Illness and Death in the United States, 5 EMERging Infectious Diseases 607, 607 (1999); see Population Div., U.S. Census Bureau, Historical Population Estimates: July 1, 1900 to July 1, 1999, http://www.census.gov/popest/archives/1990s/popclockest.txt (last visited May 3, 2010) (indicating that the U.S. population was approximately 273 million in 1999).

${ }_{18}$ See F.K. Käferstein et al., Foodborne Disease Control: A Transnational Challenge, 3 EMERGING INFECTIOUS DiSEASES 503, 506 (1997).

${ }_{19}$ WHO, WHO Global Strategy for Food Safety, supra note 15, at 5.

${ }^{20}$ See Food \& Agric. Org. [FAO] \& WHO, The Role of Food Safety in Health and Development, 12, WHO Technical Report Series 705 (1984).

${ }^{21}$ See WHO, WHO Global Strategy for Food Safety, supra note 15.

${ }^{22}$ See id. at 5; see also Käferstein et al., supra note 18, at 503; Rocourt et al., supra note 15, at 8-9 (identifying eight new conditions and practices since the $1970 \mathrm{~s}$ that contributed to this increase).

${ }^{23}$ See Rocourt et al., supra note 15 , at 11.

24 See generally Robert V. Tauxe, Emerging Foodborne Diseases: An Evolv- 
search is showing that acute infections, such as those associated with foodborne illnesses, can also result in serious chronic diseases, such as reactive arthritis and kidney and heart disease. ${ }^{25}$

This focus on foodborne infectious disease also reflects a widely held view among food scientists and public health officials that chemical hazards have been reasonably well controlled. ${ }^{26}$ Chemical residue and food additive standards are set with substantial margins of safety based on the best available scientific models. ${ }^{27}$ Compliance with chemical residue standards, at least in OECD countries, is believed to be reasonably high. There is little epidemiological evidence of overt problems. Research continues to monitor and assess the possibility of more subtle impacts, but epidemiological evidence of such impacts is more difficult to secure because the effects of doses as low as those generally found in food residues are subtle or involve long latency periods between exposure and onset of illness. ${ }^{28}$

Yet chemical hazards do remain a concern for both consumers and food safety experts. Continuing consumer concern about pesticide residues has resulted in the development of organic standards and the growth of organic food as a market sector. ${ }^{29}$ Public health concerns have focused on the effects of cumulative exposure and impacts of low doses of foodborne chemicals on sensitive populations. In 1996, the United States passed the first major pesticide legislation reform in twenty years. This legislation requires EPA to evaluate the

ing Public Health Challenge, 3 EMERging InfECTIOUS DiSEASES 425 (1997) (provides the most recent CDC estimates of the incidence of foodborne illness by causal pathogen for the United States); see also Josefa M. Rangel et al., Epidemiology of Escherichia coli O157:H7 Outbreaks, United States, 1982-2002, 11 EMERGING INFECTIOUS DISEASES 603, 603 (2005); Jill J. McCluskey et al., Bovine Spongiform Encephalopathy in Japan: Consumers' Food Safety Perceptions and Willingness to Pay for Tested Beef, 49 Austl. J. AgriC. \& ResourCE ECON. 197, 197-209 (2005) (discussing the role of British beef exports in Japan to the emergence of BSE in Japan).

${ }^{25}$ See generally James A. Lindsay, Special Issue: Chronic Sequelae of Foodborne Disease, 3 EMERGING INFECTIOUS DisEASES 443 (1997).

${ }^{26}$ Rocourt et al., supra note 15 , at 12.

27 See generally W. H. Van Eck, International Standards: The International Harmonization of Pesticide Residue Standards for Food and Drinking Water, in Pesticide Residues in Food and Drinking Water: Human Exposure and RiSks 295 (Denis Hamilton \& Stephen Crossley eds., 2004).

${ }^{28}$ See generally Les Davies et al., Chronic Intake, in PESTICIDE RESIDUES IN Food AND DRINKING WATER: HuMAN EXPOSURE AND Risks 213 (Denis Hamilton \& Stephen Crossley eds., 2004).

29 See generally Carolyn Dimitri \& Catherine Greene, Econ. Res. Serv.,

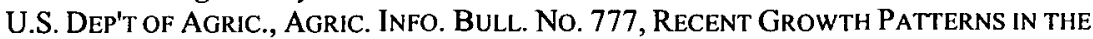
U.S. ORGANIC FoODS MARKET (2002) (providing a statistical overview of growth in organic foods markets in the United States). 
cumulative impact that low-dose exposure to multiple chemicals could have on adult and child health and to establish standards that would protect children. ${ }^{30}$ The last three decades have also seen scientific transformation, first in the life sciences and more recently in materials sciences. ${ }^{31}$ New technologies - including the development of genetically modified plants and animals, the use of growth-enhancing hormones, and the emergence of nanotechnology - have required evaluation for risk and modification of regulations. In general, European consumers seem more concerned about the health impacts of these new technologies than do consumers in the United States. ${ }^{32}$

Globalization has complicated management of both infectious and noninfectious foodborne hazards. In many developing countries, global economic integration has helped raise incomes. But it has also fostered rapid urbanization, straining sanitation and water systems needed for safe food handling. ${ }^{33}$ Rapid urbanization is also accompanied by a shift from home to commercial food production, processing, and preparation and therefore by a heightened need for training in new food hygiene management practices. Emerging economies, such as China, are moving through periods of rapid industrialization and urbanization similar to those experienced by Europe and North America in the nineteenth century. Indeed, the world is seeing the reemergence

${ }^{30}$ Food Quality Protection Act of 1996, Pub. L. No. 104-170, 110 Stat. 1489. See generally NAT'L ReSEARCH COUNCIL, PESTICIDES IN THE DieTS OF INFANTS AND CHILDREN (1993) (assessing differences in the impact of pesticides and children and adults and assessing the adequacy of existing pesticide regulation to protect infants and children).

${ }^{31}$ See generally Jean D. Kinsey, The New Food Economy: Consumers, Farms, Pharms, and Science, 83 AM. J. AGRIC. ECON. 1113 (2001) (presidential address at the 2001 American Agricultural Economics Association Meeting discussing major trends in food production, marketing, and safety).

${ }^{32}$ See, e.g., Simonetta Zarrilli, United Nations Conference on Trade and Development, International Trade in GMOs and GM Products: National and Multilateral Legal Frameworks, at 39 (2005); Frans W.A. Brom, WTO, Public Reason and Food Public Reasoning in the 'Trade Conflict' on GM-Food, 7 ETHICAL Theory \& MORAL PRAC. 417 (2004) (arguing that the conflict between free-trade treaty obligations and the cultural meanings of food demands greater attention to international food trade regulations); David Byrne, Eur. Comm'r for Health \& Consumer Prot., Address at the Food Safety Conference: The Regulation of Food Safety and the Use of Traceability/Tracing in the EU and USA: Convergence or Divergence? (Mar. 19, 2004), http://ec.europa.eu/dgs/health_consumer/library/speeches/speech 168 en.pdf (explaining the difference between European and American perspectives on food safety).

${ }^{33}$ Käferstein et al., supra note 18, at 503-04; see also WHO, WHO Global Strategy for Food Safety, supra note 15, at 6 (discussing the interaction of agricultural, health, and food marketing practices in developing and industrial nations in affecting food safety in each set of countries). 
of problems, such as intentional adulteration of products for economic gain (economic adulteration), at a level that is reminiscent of the late 1800s. Recent problems with economic adulteration of food exports from China demonstrate how increased global trade coupled with weak national food safety institutions and the difficulty of observing or detecting safety attributes of food create opportunities for consumer fraud. ${ }^{34}$ The institutional capacity of industries and governments in emerging economies needs to grow with their productive capacity. Industrializing countries should be able to benefit from the lessons advanced industrial countries learned about building food safety institutions over the past hundred years.

In almost all countries, globalization has meant more globalized food supplies. In the United States, fresh fruit imports increased from nine percent of consumption in 1985 to twenty-three percent in 2001, and vegetable imports grew from eight percent to seventeen percent. ${ }^{35}$ Without care, imported foods can also effectively result in the importation of another country's sanitation problem. The United States experienced this in a 1996 outbreak of cyclosporiasis associated with Guatemalan raspberries and a 2008 outbreak of salmonella from Mexican jalapeño peppers. ${ }^{36}$ Consumers in developed countries, such as the United States, tend to view the problem of contaminated food imports as originating solely in developing countries. But the direction of influences is not so easy to stereotype. For example, the spread of BSE to Japan and other Asian countries can be traced to British beef and cattle-feed exports in the 1990s. ${ }^{37}$

It is important to recognize that current disease levels reflect past and current investments in controlling foodborne hazards. In 1999, Belgian animal feed was accidentally contaminated with dioxin in

34 See generally Fred Gale \& Dinghuan Hu, Supply Chain Issues in ChINA'S MILK ADULTERATION INCIDENT (2009), http://ageconsearch.umn .edu/bitstream/51613/2/China\%20Dairy\%20industry\%20IAAE\%20_June2009.pdf (describing underlying economic conditions and institutional structures that contributed to adulteration of Chinese milk with melamine); see also Aleda V. Roth et al., Unraveling the Food Supply Chain: Strategic Insights from China and the $2007 R \boldsymbol{R}$ calls, 44 J. Supply Chain MGMT. 22, 22 (discussing the U.S. Food \& Drug Administration's response to adulteration of Chinese gluten with melamine).

35 Andy Jerardo, U.S. DeP'T of Agric., OUtlook Rep. No. FAU-79-01, IMPORT SHARE OF U.S. FoOd CONSUMPTION STABLE AT 11 PERCENT 5 (2003), available at http://www.ers.usda.gov/publications/fau/july03/fau7901/fau7901.pdf.

${ }^{36}$ See, e.g., Linda Calvin et al., Case Study: Guatemalan Raspberries and Cyclospora, in 10 Focus: FoOd SAFETY in FoOd SECURITY AND FoOd (2003), available at http://www.ifpri.org/sites/default/files/publications/focus10_07.pdf.

37 Jill J. McCluskey et al., Bovine Spongiform Encephalopathy in Japan: Consumers' Food Safety Perceptions and Willingness to Pay for Tested Beef, 49 Austl. J. AGRIC. \& RESOURCE ECON. 197, 198 (2005). 
polychlorinated biphenyls (PCBs) and distributed to approximately 2,500 farms. ${ }^{38}$ In the winter of 2008 to 2009 , salmonella originating from a Georgia peanut processor sickened more than 700 people in forty-six states. ${ }^{39}$ That salmonella outbreak was caused by a leaking roof and poor hygiene conditions that the processing plant failed to address despite public inspectors' awareness of the problem. These incidents serve as a reminder that failures in private management and public enforcement are always possible, even in countries considered to have strong food safety practices and institutional safeguards. ${ }^{40}$ They also serve as a reminder that without continued control, old problems, such as tuberculosis, can reemerge.

\section{FOUNDATIONS FOR FOOD SAFETY POLICY REFORM AROUND THE GLOBE}

The 1990s and 2000s saw three major innovations in food safety policy: expansion of the role of multinational institutions; emergence of an international consensus around the basic components of a modern structure for food safety policy; and national-level reform of food safety law. These innovations embody broader policy agendas that have roots going back almost half a century that coalesced in the face of recent food safety crises. These agendas include introduction of scientific management practices into public administration, particularly since the 1960s; adoption of total quality management as a conceptual framework for process engineering in the United States and Europe, again particularly since the 1960s; and a continued commitment to global integration of markets since World War II.

\section{A. Science-Based Public Decision Analysis}

In both the private and public sectors, the post-World War II period has been characterized by a drive for greater rationalization in decision-making, particularly risk management and decision-making under uncertainty. ${ }^{41}$ Food safety management and policy have at times led and at times benefited from this drive.

38 See ElAmin, supra note 5.

39 Ctrs. for Disease Control \& Prevention, Dep't Health \& Human Servs., Investigation Update: Outbreak of Salmonella Typhimurium Infections, 2008-2009 (Apr. 29, 2009), http://www.cdc.gov/salmonella/typhimurium/update.html.

${ }^{40}$ See generally Adrian Covaci et al., The Belgian PCB/Dioxin Crisis-8 Years Later: An Overview, 25 Envtr. Toxicology \& PhaRmacology 164 (2008).

41 Two threads have emerged as particularly central to policy: rationalized risk management as a paradigm for public governance of health, safety, and environmental hazards and processing engineering controls systems to food processing. See 
Food safety policy is among the oldest areas of modern consumer safety. In the United States, federal agencies have a long history of applying risk analysis to guide public decisions. Much as we are seeing a revolution in life sciences today, the 1940s and 1950s were a period of revolutionary development in applied chemistry. One such area of application was food additives. In 1954, Lehman and Fitzhugh suggested the use of safety factors to establish acceptable daily intake of food additives on the basis of acute toxicity. ${ }^{42}$ A safety factor approach to risk assessment is still used in setting food standards today. ${ }^{43}$ Lehman-Fitzhugh's model included a safety threshold below which chemicals are assumed to have no effect. Controversy about whether such a threshold exists for carcinogens led to a 1958 amendment to the Food, Drugs, and Cosmetic Act of 1938, known as the Delaney Clause. This legislation effectively prohibited sale in the United States of foods that contained additives shown to be carcinogenic. $^{44}$ As the analytical ability to detect residues increased, arguments about the appropriateness of the Delaney Clause's nonthreshold model grew. In 1973, the FDA abandoned the nonthreshold doseresponse model for carcinogens after concluding that there was inadequate scientific basis for this modeling assumption. ${ }^{45}$

In 1981, public controversy over FDA's abandonment of the use of the nonthreshold model prompted the U.S. Congress to call for a National Academy of Sciences (NAS) committee to evaluate the merit of creating an independent institution to conduct risk assessments for

Richard N.L. Andrews, Risk-Based Decision Making: Policy, Science, and Politics, in Environmental Policy in the Twenty-Firs't Century 215-38 (Norman Vig \& Michael Kraft eds., 2006) (discussing the role of decision analysis and risk management in U.S. environmental policy); NAT'L RESEARCH COUNCIL, SCIENTIFIC CRITERIA TO ENSURE SAFE FOOD 70 (2003). From an economics perspective, both fit into the legacy of von Newman and Morgenstern in the rich literature on expected utility theory and rationalizing decision-making under uncertainty. JOHN VON NEUMANN \& OSKar Morgenstern, TheORY OF GAMES AND ECONOMIC BEHAVIOR (1944). For a general introduction to the academic and management literature on decision-making under uncertainty, see Robert T. Clemen, Making HaRd DECISIONS: AN INTRODUCTION TO DECISION ANALYSIS (1996).

${ }^{42}$ See A.J. Lehman \& O.G. Fitzhugh, 100-Fold Margin of Safety, 18 Q. BULL. Ass'N FoOd \& Drug OFFICIALS U.S. 33, 33-35 (1954) (providing early scientific justification for FDA's hundredfold margin of safety for chemical residues in food).

${ }^{43}$ See, e.g., Codex Alimentarius COMm'N, COdex General Standard for FoOD AdDiTIVES: CODEX STAN 192-1995 (2009), http://www.codexalimentarius.net/ gsfaonline/CXS_192e.pdf.

${ }^{44}$ Food Additives Amendment of 1958, Pub. L. No. 85-929, $\$ 409,72$ Stat. 1784, 2151-52 (amended 1964).

${ }_{45}$ See Robert J. Scheuplein, Risk Assessment and Food Safety: A Scientist's and Regulator's View, 42 Food Drug COSM. L.J. 237, 240 (1987). 
all federal agencies. ${ }^{46}$ The study summarized practices federal agencies were developing to use scientific analysis of risks to assess and manage risks. It described risk analysis as a three-part process: risk assessment, risk management, and risk communication. ${ }^{47}$ Although the committee recommended separating the risk assessment and risk management functions to protect the integrity of the scientific analysis, it did not recommend creating an independent risk assessment institution. The study, dubbed the "Red Book" because of its cover color, quickly became the "bible" of risk analysis for federal agencies.

It is difficult to overstate the influence of the NAS Red Book. It is still looked to as the basic framework for risk regulation by both U.S. agencies and governments around the world. Its publication and use have stimulated discussion about the role of risk analysis in governance of consumer and environmental risk in Europe as well as in the United States. ${ }^{48}$ As will be seen, the Red Book has had direct influence on the shape of international food safety policy and national policy worldwide.

Since publication of the Red Book, risk analysis has played a central role in U.S. environmental policy administration. In the 1980s, the White House sought to exert control over the agendas of U.S. health and safety agencies through Office of Management and Budget (OMB) oversight. Andrews argues that risk analysis gave regulatory agencies, particularly the Environmental Protection Agency (EPA), a way to shift OMB's cost-benefit analysis toward science-based, outcome-focused analysis. ${ }^{49}$ In the 1980s and 1990s, the EPA experi-

\footnotetext{
46 Nat'l Research Council, Risk Assessment in the Federal Government: MANAGING THE Process 2 (1983).

${ }^{47}$ Risk assessment is the scientific evaluation of the level of risk faced by a population of concern. It typically involves assessment, dose-response, and risk characterization. Risk management is regulation or policy decision-making. Risk communication focuses on communicating results not only to the public, but also among policy circles. Food Safety \& Inspection Serv., U.S. Dep't of Agric., Production \& Inspection: Risk Analysis, http://www.fsis.usda.gov/factsheets/Risk_Analysis/ index.asp (last visited May 3, 2010).

48 See Marion Dreyer \& Ortwin Renn, The Scientific Approach to Comparing Institutional Rearrangements in European Food Safety Governance, in FOOD SAFETY

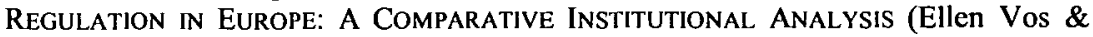
Frank Wendler eds., 2006); see also CARNEGIE COMM'N ON SCI., TECH., \& Gov'T, RisK aND THE ENVIRONMENT: IMPROVING REgULATORY DECISION MAKING (1993). For an insightful comparison of risk regulatory systems in the United States and Europe, see Jonathan B. Wiener, Whose Precaution After All? A Comment on the Comparison and Evolution of Risk Regulatory Systems, 13 DUKE J. COMP. \& INT'L L. 207 (2003).

49 Richard N.L. Andrews, Managing the Environment, Managing OURSElves: A History of AMERICAN ENVIRONMENTAL POLICY (1999); see also
} 
mented with comparative risk ranking projects to help inform agency priority setting. ${ }^{50} \mathrm{OMB}$ and what was then called the General Accounting Office (GAO) encouraged "other agencies to use comparative risk assessment coupled with a goal of risk reduction to set budget priorities. ${ }^{, 51}$ In the end, the EPA concluded that available risk information was simply too coarse for budgeting purposes and the agency's priorities too constrained by legislative mandate. ${ }^{52}$ Although comparative risk ranking did not fulfill its promise as a budgeting tool, it is helpful in finding useful applications to the narrower problems of prioritization in food safety policy. ${ }^{53}$

Comparative risk ranking to inform priority setting has more critical limitations, however. In particular, used alone it ignores the relative cost-effectiveness of alternative control options. It also ignores the way citizens feel about different risks, about reducing one risk relative to another, and about reducing health risks relative to other outcomes they want to achieve. A parallel set of public administration reforms beginning in the 1960s sought to address these issues through the introduction of modern financial management practices from the private sector into public administration. The United States saw an acceleration in use of quantitative policy analysis by federal agencies following Robert McNamara's introduction of systems analysis, such as the Planning, Programming, and Budgeting System (PPBS), as a

Andrews, supra note 41 . For a history of the use of risk analysis and cost-benefit analysis at U.S. EPA, see LINDA-Jo SCHIEROw, RISK ANALYSIS AND COST-BENEFIT ANALYSIS OF ENVIRONMENTAL REGULATIONS, CRS REPORT 94-961, available at http://ncseonline.org/nle/crsreports/risk/rsk-5.cfm (last visited May 3, 2010).

${ }^{50}$ See F. Henry Habicht II, EPA's Vision for Setting National Environmental Priorities, in Worst Things First? The Debate over Risk-Based National ENVIRonmental Priorities 35-36 (Adam M. Finkel \& Dominic Golding eds., 1994); Richard A. Minard Jr., CRA and the States: History, Politics, and Results, in Comparing Environmental Risks: ToOls for Setting Government Priorities 27-33 (J. Clarence Davies ed., 1996). U.S. Envt'L Protection AgENCY, UnFINISHEd Business: A COMParative ANalysis of ENVIRONMENTal Priorities (1987); U.S. Envt'l Protection Agency, Reducing Risk: Setting Priorities and Strategies FOR ENVironmental Protection (1990).

5121 Env't Rep. (BNA) No. 41 at 1796 (Feb. 8, 1991).

52 Id.

53 See Risk AsSesSment Div., U.S. Dep't of AGRIC., FSIS Risk ASSESSMENT FOR RISK-BASED VERIFICATION SAMPLING OF LISTERIA MONOCYTOGENES (2007); U.S. Gov't ACCOUNTABIlity OfFice, FoOd SafeTy: Selected Countries' SYSTEMS CAN OFFER INSIGHTS INTO ENSURING IMPORT SAFETY AND RESPONDING TO FOODBORNE ILLNESS 15 (2008) [hereinafter FOOD SAFETY] (describing various countries' use of risk ranking in setting import inspection priorities). For a general set of recommendations on the role risk ranking could play in food safety policy, see TOWARD SAFER Food: Perspectives on Risk and Priority Setting 10 (Sandra A. Hoffmann \& Michael R. Taylor eds., 2005) [hereinafter Toward SAFER FOOD]. 
means of rationalizing strategic planning efforts by the Department of Defense in the 1960s. In the 1970s, use of analysis that incorporated consideration of costs, impact, and social preferences increased as New Society programs were implemented and expanded. ${ }^{54}$ Since the Reagan administration, cost-benefit analysis has been required for all major environmental and health and safety regulation. ${ }^{55}$ The Government Performance Results Act of 1993 required performancebased budgeting of all U.S. agencies. ${ }^{56}$ Other OECD countries require similar decision analysis in public decision-making. ${ }^{57}$

\section{B. Risk-Based Industrial Process Management}

First-generation food safety policy relied heavily on line inspection to ensure product quality. In the United States, the Meat Inspection Act of 1906 required continuous visual inspection of meat slaughter and processing lines. ${ }^{58}$ Line inspection reflects industrial quality management practices of the early 1900s. This was an effective means of enforcing hygiene practices and detecting visible signs of diseases, such as trichinosis or tuberculosis. But one hundred years later, it remains law even though current safety problems, primarily microbiological and chemical, cannot be detected through visual line inspection. $^{59}$

54 Kaifeng Yang, Quantitative Methods for Policy Analysis, in HaNDBOOK OF Public Policy ANALYSIS: THEORY, Politics AND MEthods 349-53 (Frank Fischer, Gerald Miller and Mara Sidney eds., 2007).

55 Exec. Order No. 12291, 46 Fed. Reg. 13,193 (Feb. 19, 1981).

56 Exec. Order No. 12866, 58 Fed. Reg. 51,735 (Oct. 4, 1993), amended by Exec Order No. 13258, 67 Fed. Reg. 9,385 (Feb. 28, 2002), amended by Exec. Order No. 13422, 72 Fed. Reg. 2,763 (Jan. 23, 2007) (creating a legal requirement for federal agencies to conduct regulatory impact assessment and cost-benefit analysis of major federal regulations); Government Performance and Results Act of 1993, Pub. L. No. 103-62, $\$ \$ 1115-1116,107$ Stat. $285,287-88$ (requiring federal agencies to conduct formal strategic planning and annual agency-wide performance reviews).

57 See, e.g., Her Majesty's Treasury, The Green Book: Appraisal and Evaluation in CENTRAL Government (2003); see also Treasury Bd. of Can. Secretariat, Regulatory Affairs: Cabinet Directive on Streamlining Regulation, http://www .tbs-sct.gc.ca/ri-qr/directive/directive00-eng.asp (last visited May 3, 2010) (providing guidance on the conduct of regulatory impact analysis in the United Kingdom and Canada, respectively). For a review of performance-based budgeting practices in OECD countries, see Aidan Ros, Results-Oriented Budget Practice, in OECD Countries Overseas Development Institute Working Paper $209 \mathrm{http}: / / \mathrm{www}$. odi .org.uk/resources/download/1377.pdf (last visited May 3, 2010).

${ }^{58}$ Federal Meat Inspection Act of 1906, 34 Stat. 674-679 (1906) (current version at 21 U.S.C. $\$ \S 601-695$ (2006)).

59 See Meat Safety: Inspectors' Ability to Detect Harmful Bacteria is Limited: Hearing before the Subcomm. on Agricultural Research, Conservation, Forestry, and General Legislation of the Comm. on Agriculture, Nutrition and Forestry, 
Even by the 1930s, manufacturers were replacing line inspection with more analytical quality control methods such as statistical batch sampling to improve the efficiency of inspection. ${ }^{60}$ During World War II, the U.S. military began developing analytical management processes, such as failure mode and criticality analysis, to assess the reliability of equipment and procedures and to prevent failures. ${ }^{61}$ After the war, the National Aeronautics and Space Administration (NASA) further developed these processes to prevent costly failures in rocket programs, where failures in small batches could fail a mission. In its various forms, failure and criticality analysis were part of the broader postwar movement in industrial engineering toward reliance on total quality control systems. ${ }^{62}$ In the late 1950s, NASA asked Pillsbury, a major U.S. food-processing firm, to adapt these techniques for use in developing food products that met the very high safety reliability needs of manned space flight. This request resulted in a process for food application called Hazard Analysis and Critical Control Point (HACCP) systems. ${ }^{63}$

HACCP provides a systematic way to identify foodborne hazards, assess their criticality, and control weak points through which they are most likely to enter a food production system. The process begins with a hazard analysis that develops a detailed description of the food, its physical and biological properties, its intended use and consumers, and a verified flow diagram of the process and inputs used to produce and distribute the food. ${ }^{64}$ HACCP has been promoted as providing

103rd Cong. 1-3 (1994) (statement of John W. Harman, Director of Food and Agricultural Issues, Resources, Community, and Economic Development Division of the U.S. General Accounting Office). Based on personal observation of food safety reform debates over the past decade and discussions with senior food safety officials, there appear to be multiple reasons why line inspection has not been abandoned. Among them are resistance from a well-established inspectors union and a lack of certainty about what would happen if the continuous inspection requirement were removed.

${ }^{60}$ See generally W. A. SHEWharT, ECONOMIC CONTROL OF QuALITY of MANUFACTURED PRODUCT (1931) (foundational work on statistical quality control by an early leader of Bell Telephone Laboratories).

${ }^{61}$ Dep't of Def., Procedure for Performing a Failure Mode Effect and Criticality ANalysis MIL-P-1629 (1949).

${ }_{62}$ See generally Junji Noguchi, The Legacy of W. Edwards Deming, 28 QUALITY ProGress 35, 35-37 (1995) (discussing W. Edwards Deming's role in establishing total quality control systems as central to industrial quality management in Japan and the United States).

${ }^{63}$ For a historical overview, see Karen L. Hulebak \& Wayne Schlosser, Hazard Analysis and Critical Control Point (HACCP) History and Conceptual Overview, 22 RisK ANALYSIS 547 (2002).

${ }^{64}$ Nat'l Advisory Comm. on Microbiological Criteria for Foods, U.S. Food \& Drug Admin., Hazard Analysis and Critical Control Point Principles and Guide- 
firms with the flexibility to adapt to changing conditions, because its standard is whether a functional control system is in place and the system under control, rather than the mandated use of specific controls, as was typical under conventional hygiene regulations. It also provides firms with the flexibility to respond to changing relative prices and control hazards more cost-effectively.

Like other forms of failure and criticality analysis, HACCP gained wide adherence in industry and public health circles as an effective way to prevent system failure. This has been particularly true in the area of controlling microbiological hazards. HACCP found fairly quick acceptance among national governments and international institutions. ${ }^{65}$ In 1993, the Codex Alimentarius Commission (Codex) issued HACCP guidelines and included it in its Recommended International Code of Practice in $1995 .^{66}$ Shortly thereafter, U.S. food safety agencies began to shift to the use of HACCP as their basic regulatory approach for controlling microbial hazards. ${ }^{67}$

HACCP has received a more mixed response from the food industry and consumers. For large firms, it fits fairly naturally with other industrial engineering management practices. But HACCP requires relatively sophisticated administration and management, and it therefore can impose a significant burden on smaller firms in the food industry. In the United States, federal agencies have responded to small firms' concerns with technical assistance programs. ${ }^{68}$ U.S. consumer groups have generally supported HACCP but insist that without enforceable performance standards, it provides no way to hold industry accountable for producing safe food. ${ }^{69}$ The scientific community is actively engaged in research to develop such standards. ${ }^{70}$

lines (Aug. 14, 1997), http://www.fda.gov/Food/FoodSafety/HazardAnalysisCritical ControlPointsHACCP/ucml 14868.htm.

${ }^{65}$ TOWARD SAFER FoOD, supra note 53, at 12.

${ }^{66}$ Laurian Unnevehr \& Helen Jensen, The Economic Implications of Using HACCP as a Food Safety Regulatory Standard, 24 Food POLICY 625 (1999).

${ }^{67}$ See infra text accompanying note 233.

${ }^{68}$ FoOd SAFETy \& INSPECTION SERV., U.S. Dep'T OF AgRIC., FSIS Microbiological Hazard Identification Guide for Meat and Poultry Components of Products Produced by Very Small Plants (1999), http://www.fsis.usda.gov/Frame/FrameRedirect.asp?main=http://www.fsis.usda.gov/ $\mathrm{OA} / \mathrm{haccp} / \mathrm{hidguide.htm}$.

69 See Michael F. Jacobson, Ctr. fOr SCl. in the Pub. Interest, COMMISSIONER'S CONSUMER ROUNDTABLE (2000), http://www.goodnutrition.org/ reports/mjcomments_cfsan.html.

${ }_{70}$ See InSt. OF MED., NAT'l Research COUNCIL, SCIENTIFIC CRITERIa to Ensure Safe Food (2003); Codex Alimentarius Comm'n, Principles for the

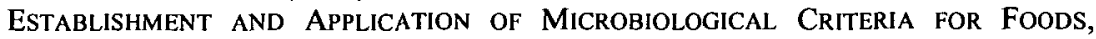
CAC/GL 21 (1997), available at www.codexalimentarius.net/download/standards/ 


\section{ECONOMIC GLOBALIZATION AND THE RISE OF INTERNATIONAL FOOD SAFETY GOVERNANCE}

Broader government commitments to greater economic integration, both globally and regionally, have had, and will continue to have, significant impact on food safety policy. The General Agreement on Trades and Tariffs (GATT), negotiated in the wake of World War II, remains the central framework for international trade. Since 1947, GATT's goal has been to liberalize trade through successive rounds of negotiation guided by the principles of equal treatment for trading partners, transforming nontariff barriers to tariffs, and negotiating reduced tariffs over time. ${ }^{71}$ GATT recognizes limited exceptions to its general requirements. One of the most important is the exception for actions required to protect health, under which parties to the agreement may adopt laws "necessary to protect human, animal or plant health" as long as they are "not applied in a manner which would constitute a means of arbitrary or unjustifiable discrimination between countries where the same conditions prevail, or a disguised restriction on international trade." ${ }^{, 72}$

The Uruguay Round of negotiations (1986-1994) created a permanent institutional home for GATT within the WTO. ${ }^{73}$ An updated version of the 1947 agreement remains the core of the new GATT 1994. ${ }^{74}$ More critical for food safety, the Sanitary and Phytosanitary (SPS) Agreement was negotiated during the Uruguay Round to provide a basis for distinguishing legitimate from protectionist use of safety and phytosanitary laws and to encourage their legitimate use. ${ }^{75}$ The agreement, effective as of 1994 , is one of roughly sixty that WTO signatories have ratified. ${ }^{76}$

394/CXG_021e.pdf.

${ }^{71}$ General Agreement on Tariffs and Trade art. I, Oct. 30, 1947, 61 Stat. A11,55 U.N.T.S. 194. Nontariff barriers to trade are barriers to trade that are not in the form of a tariff. They include things such as subsidies to domestic industries, import quotas, and standards that differentially impact foreign suppliers.

${ }^{72} \mathrm{Id}$. art. XX.

${ }^{73}$ WHO, Understanding the WTO: Basics, The Uruguay Round, http://www .wto.org/english/thewto_e/whatis_e/tif_e/fact5_e.htm (last visited May 3, 2010).

${ }^{74} \mathrm{Id}$.

${ }^{75}$ See WHO, Food Safety and Globalization of Trade in Food: A Challenge to the Public Health Sector, at 1, WHO/FSF/FOS/97.8 Rev. 1 (1998), available at $\mathrm{http} / / / \mathrm{www}$.who.int/foodsafety/publications/fs_management/en/globalization.pdf.

This is not dissimilar to the role played by risk assessment and regulatory impact assessment in development of U.S. law. The Agreement on Technical Barriers to Trade (TBT) also adopted in the Uruguay Round, governs all other technical requirements and standards, including labeling, not covered by the SPS Agreement. Id.

${ }^{76}$ For a general treatise on international trade law, see PETER VAN DEN 
While reiterating commitment to the health exception to GATT, the SPS Agreement seeks to provide greater certainty about when national sanitary and phytosanitary laws comply with GATT and to reduce their impact on trade by promoting harmonized laws. ${ }^{77} \mathrm{Mem}-$ ber states agree "to ensure that any sanitary or phytosanitary measure is applied only to the extent necessary to protect human, animal or plant life or health" ${ }^{\text {"78 }}$ and that measures are "based on scientific principles" and supported by "sufficient scientific evidence." M9 Measures may not "arbitrarily or unjustifiably discriminate between members" under "identical or similar conditions" restrictive than needed to achieve the member state's "acceptable risk" level. ${ }^{81}$

Under the SPS Agreement, signatories agree to base their national measures on international standards, where they exist. ${ }^{82}$ National rules that conform to international standards are viewed as complying with the SPS and GATT agreements. ${ }^{83}$ Signatories are free to set a higher level of protection than could be achieved based on international norms or adopt national norms where no international ones exist as long as they provide scientific justification or find it appropriate based on a risk assessment consistent with SPS guidelines. Annex A

Bossche, The law and Policy of the World Trade Organization: Text, Cases and Materials (2005); see also Peter Gallagher, The First Ten Years of the WTO: 1995-2005, at 7 (2005) (commissioned by the WTO to provide a factual account of the transition from the GATT to the WTO). For a well-designed empirical evaluation of the influence of individual countries on Codex and the influence of Codex on national food safety law, see DiahanNa LYNCH POST, FoOd Fights: WhO Shapes InTERnational Food SAFETy STANDARdS AND Who Uses Them (2005); see also Tim Josling et al., Food Regulation and TRAde: Toward a Safe and Open GLOBAL SYSTEM 40-51 (examining the interaction between international trade and food safety policy goals from a political economy perspective). For an accessible but comprehensive treatment of European Union Food Law, see BERND VAN DER MEULEN \& Menno van der Velde, European Food Law Handbook 467-81 (2008) (This work assumes no prior understanding of European Union law and is a very accessible entry point into this area of law for those new to law or to EU law. It is also complete enough to serve as a good reference book for those with substantial knowledge of the area.).

${ }^{77}$ Agreement on the Application of Sanitary and Phytosanitary Measures, Apr. 15, 1994, Marrakesh Agreement Establishing the World Trade Organization, Attachment to Annex 5, art. 2.1, Legal Instruments - Results of the Uruguay Round, 1867 U.N.T.S. 493 (1994) [hereinafter SPS Agreement].

${ }^{78}$ Id. at art. 3.1.

79 Id. at art. 2.2.

${ }^{80} \mathrm{Id}$. at art. 2.3.

${ }^{81}$ Id. at art. 2.6, Annex A.5.

82 Id at art. 3.1.

${ }^{83}$ Id. at art. 3.2. 
of the SPS Agreement defines international standards, guidelines, and recommendations for food safety as those established by Codex ${ }^{84}$ Under the SPS Agreement, members agree to follow risk assessment principles adopted by relevant international organizations. ${ }^{85}$ These assessments must take available scientific evidence into account. They may also consider economic factors, including "potential damage in terms of loss of product or sales in the event of the entry, establishment, or spread of a pest or disease; the cost of control or eradication in the territory of importing members; [and] the relative cost-effectiveness of alternative approaches. ${ }^{.86}$

Like other GATT provisions, the SPS Agreement is enforced by international dispute resolution and, if necessary, trade sanctions levied by injured countries against offending ones. A country may refuse entry of products that do not meet the standards it imposes on its own industries as long as those standards are consistent with GATT. SPS signatories also agree to accept the food safety rules of other nations as equivalent to their own if the exporting country demonstrates that its rules can achieve the same level of protection as the importing members' rules. $^{87}$

The SPS Agreement is intended to make it easier for all countries to participate in international trade by creating greater certainty about when food safety rules comply with GATT and promoting harmonization of rules. It recognizes, however, that compliance with these rules may make it more difficult for developing countries to be involved in international trade, and thus it encourages wealthier members to provide or fund technical assistance ${ }^{88}$ to help poorer countries develop food safety systems that comply with the SPS Agreement and to grant time extensions to poorer countries for compliance with SPS obligations. ${ }^{89}$

\section{A. The Evolving Role of Codex Alimentarius}

The Codex Alimentarius Commission was established in 1961 by the United Nations' Food and Agriculture Organization (FAO) and World Health Organization (WHO) to provide a forum for interna-

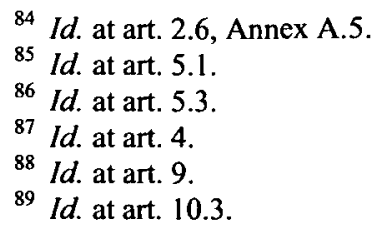


tional technical collaboration on the development of food safety and quality standards. ${ }^{90}$

The commission was created with two primary goals: protecting human health and promoting fair trade practices. ${ }^{91}$ It pursues both by serving as a venue for development of mutually agreed upon model standards, principles, and guidelines that provide guidance to national governments for use in developing their own laws and guidelines. ${ }^{92}$ The recognition of Codex norms as presumptively compliant with the GATT under the SPS Agreement is likely to give the Codex Commission greater weight in future national regulatory and legislative development. ${ }^{93}$ Although Codex norms are not binding on nations, they have become the standard against which national laws are measured.

Codex Commission membership is open to nations that are members or associate members of the WHO and FAO. ${ }^{94}$ Other countries, ${ }^{95}$ international nongovernmental organizations, and other individuals and organizations, may participate as observers. ${ }^{96}$ At any one time, roughly 175 countries, representing approximately ninety-eight percent of the world's population, participate in Codex. ${ }^{97}$

The Codex Commission works through a system of technical subject matter committees and regional subcommittees. These committees work to prepare and revise draft standards through a formal procedure of iterative review by the commission and member governments. ${ }^{92}$ Under its procedural rules, the Codex Commission is committed to decision by consensus, with majority vote as a last resort. $^{99}$

Much of the Codex Commission's and committees' efforts have gone into producing model standards. These include commodity standards aimed at preventing consumer fraud, quantitative standards

${ }^{90}$ FAO \& WHO, Understanding THE CODEX Alimentarius (3rd ed. 2006). For a brief article explaining the structure and work of Codex, see Eddie Kimbrell, What is Codex? 3 AGBioForum 197-202 (2000).

91 FAO \& Who, Codex Alimentarius Commission Procedural Manual $\S \mathrm{I}$, art. 1(a), at 4 (18th ed. 2008).

92 VAN DER MEULEN \& VAN DER VELDE, supra note 76, at 473.

93 POST, supra note 76.

94 FAO \& WHO, supra note 91 , at 4.

95 VAN DER MEULEN \& VAN DER VELDE, supra note 76, at 472.

96 FAO \& WHO, supra note 91 , at 4.

${ }^{97} \mathrm{Id}$. at 20.

98 Id. at 28.

99 Id. Final decisions on adoption of standards, principles, and guidelines are made by the commission. Some standards may be relevant only to particular regions or a smaller set of nations. In these cases, only these member states may vote. $I d$. 
for food additives, and quantitative tolerances for contaminants such as pesticides and veterinary drugs. The commission has also developed a set of recommended practices referred to as codes of practice or guidelines. These include guidelines for HACCP systems and an international food hygiene code. ${ }^{100}$ The Codex Commission has adopted "more than 200 standards, close to 50 food hygiene and technological codes of practice, some 60 guidelines, over 1,000 food additives and contaminants evaluations and over 3,200 maximum residue limits for pesticides and veterinary drugs."

Beginning in the mid-1990s, the Codex Commission began to look to risk analysis as a basic framework for developing standards and guidance. ${ }^{102}$ The influence of the NAS 1983 Red Book is evident. Codex embodies the Red Book structure of viewing risk analysis as involving risk assessment, risk management, and risk communication. ${ }^{103}$ Codex defines risk assessment as a "scientifically based" process involving four steps: hazard identification, hazard characterization, exposure assessment, and risk characterization. ${ }^{104}$ Risk management is defined as "the process, distinct from risk assessment, of weighing policy alternatives, in consultation with all interested parties, considering risk assessment and other factors relevant for the health protection of consumers and for the promotion of fair trade practices, and, if needed, selecting appropriate prevention and control options." 105 Under Codex, risk communication is focused on communications among all interested parties during the risk analysis process "about risk, risk-related factors and risk perceptions."

Codex guidelines recommend that food safety regulatory decisions be guided by risk assessment. Risk assessment should be based on science, using quantitative data to the greatest extent possible, and documented transparently. The guidelines also recommend that risk

100 See Codex Alimentarius Comm'n, Recommended International Code of Practice: General Principles of Food Hygiene, CAC/RCP 1-1969, Rev. 3, in Food Hygiene Basic TeXts 1-32 (1997); Codex Alimentarius Comm'n, Hazard Analysis and Critical Control Point (HACCP) System and Guidelines for Its Application, Annex to CAC/RCP 1-1969, Rev. 3, in FoOd HyGIENE BASIC TEXTs 33-45 (1997).

101 VAN DER MEULEN \& VAN DER VELDE, supra note 76, at 473.

102 FAO \& WHO, supra note 91, at 171-73. Codex guidance on use of risk analysis by the commission and its subcommittees was greatly expanded in 2003, with the addition of a set of "Working Principles for Risk Analysis," and further elaborated with provisions for applying risk analysis to specific areas of work in 2007 , with a statement of principles concerning science the extent to which other factors are taken into account. Id. at 67-108.

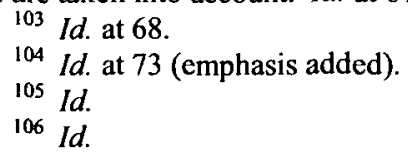


assessment and risk management be functionally separated "to protect the scientific integrity of the risk assessment." ${ }^{107}$ The Codex Commission itself adheres to this separation. The Codex Commission and its subsidiary bodies have risk management responsibility. Joint FAO/WHO expert bodies conduct risk assessments. ${ }^{108}$ But Codex guidelines also recognize that some interaction between risk management and risk assessment is necessary from a pragmatic perspective. ${ }^{109}$

The purpose of risk assessment is to provide a quantitative or qualitative estimate of the probability and severity of adverse health effects in a population of concern. ${ }^{110}$ Under Codex guidelines, risk assessments should be based on a comprehensive treatment of all scientific data, whether quantitative or qualitative. They should also take into account "relevant production, storage and handling practices used throughout the food chain including traditional practices, methods of analysis, sampling and inspection and the prevalence of specific adverse health effects." ${ }^{111}$ Risk assessments should also be based on realistic exposure scenarios. The guidelines specifically mention that, where relevant to a particular policy decision, exposure scenarios consider impacts on susceptible and high-risk population groups, as well as acute, chronic, and cumulative or combined health impacts. ${ }^{12}$ Similarly, conditions and data from different parts of the world, including developing countries, should be included in risk assessments where relevant. ${ }^{113}$

Under Codex procedures, risk management decisions are to be based on risk assessments. While they may consider legitimate factors relevant to the promotion of fair practices in food trade, their primary objective should be consumer health protection. ${ }^{114}$ "Unjustified differences in the level of consumer health protection to address similar risks in different situations should be avoided."115 Risk management decisions should also "take into account relevant production, storage and handling practices used throughout the food chain including traditional practices, methods of analysis, sampling and inspec-

107 Id. at 69. The Codex guidelines leave it to member states to determine how to separate risk assessment and risk management.

${ }_{108} I d$. at 68.

$109 \mathrm{Id}$.

110 Id. at 73 (defining risk characterization).

111 Id. at 70.

$112 \mathrm{Id}$.

113 Id.

114 Id. at 71.

115 Id. at 70. 
tion, feasibility of enforcement and compliance, and the prevalence of specific adverse health effects." ${ }^{116}$ Codex sees food safety risk management as an adaptive management process, explicitly noting the need to revise decisions and standards over time in light of new data. ${ }^{117}$

Codex guidelines on risk analysis were strongly influenced by the role the politicization of science played in Europe's BSE scandals. To avoid this kind of political influence, Codex guidelines recommend limiting interaction between risk managers and risk assessors and seek to make such interactions as transparent as possible. Risk managers are responsible for defining the scope and purpose of the particular risk assessment and the form of outputs needed from the risk assessment. ${ }^{18}$ They may also ask risk assessors "to evaluate the potential changes in risk resulting from different risk management options." 119

These provisions have the potential to affect the contribution economic analyses can make to food safety policy. Codex standards are a model for national standards, and the Codex guidelines on risk analysis are being looked to as a model for the role of risk analysis in national policy analysis. Economics is generally viewed by noneconomists involved in risk analysis as part of risk management and not risk assessment. But risks are created by human behavior in a physical and biological environment, and economics is a behavioral science that has long been used to look at how humans create and react to risk. As a result, economic analysis has the potential to make important contributions to risk assessment as distinct from its role in risk management. For example, it plays a role in exposure assessment in estimation of food consumption or could make significant contributions to sensitivity analysis by modeling how firms might change their input use in response to changing technology options or market conditions. Other social sciences have similar roles to play. If separating risk management from risk assessment leads to isolating economic and other social sciences from "scientific" analysis, less accurate estimates of health risks may result. ${ }^{120}$ At the same time, as Williams and Thompson point out, the "scientific" rather than managerial role

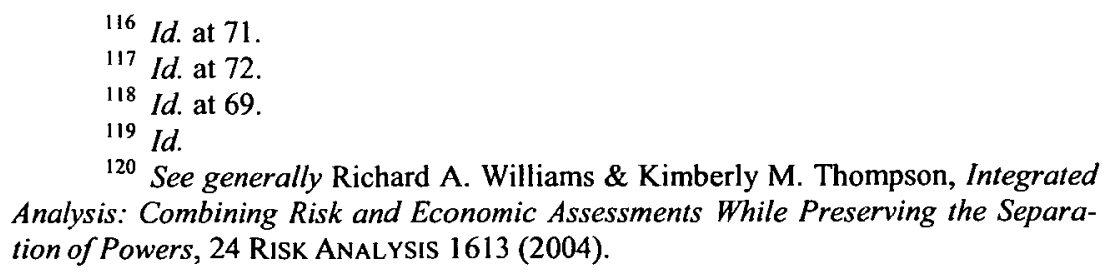

${ }^{120}$ See generally Richard A. Williams \& Kimberly M. Thompson, Integrated Analysis: Combining Risk and Economic Assessments While Preserving the Separation of Powers, 24 RISK ANALYSIS 1613 (2004). 
of social science analysis also needs protection from political pressure, just as "hard" science analysis does. ${ }^{121}$

The Codex Commission's contributions to raising the standard of food safety globally are often underappreciated. Negotiations over Codex standards and guidance allow nations to develop a common understanding, vocabulary, and frame of reference. But perhaps the most important harmonizing influence of Codex has been the development of a strong international community of technical experts on food and food safety. This is an explicit goal of Codex, which it fosters by sponsoring global and regional conferences to provide national food safety regulators with less formal opportunities for regular dialog. ${ }^{122}$ In part as a result of Codex, international cooperation and scientific consultation are the norm in food safety technical circles. Codex meetings provide a stable forum for discussion of technical issues, and Codex procedures encourage work toward consensus on best practices. Those discussions would influence the direction of national policy development even if an international standard is not adopted. In their treatise on European food law, van der Meulen and van der Velde describe how these discussions affect lawyers involved in Codex, but the same is true for scientists, and this may have an even deeper influence on national policy because of the importance of technical expertise in the development of food safety policy. ${ }^{123}$ In a well-documented dissertation, Post finds evidence that where Codex acts before nations develop standards, such as in HACCP and microbial risk assessment, it has played a significant role in shaping national policy, but in areas where it acts after national rules have already been established, it has less influence. ${ }^{124}$ The new status of Codex under the SPS Agreement seems likely to result in greater politiciza-

121 Id.

122 "Conferences such as the first Global Forum of Food Safety Regulators (GF-1) (Marrakesh, January 2002) and the Pan-European Conference on Food Safety and Quality (Budapest, February 2002) provide an opportunity for food safety regulators in developed and developing countries to exchange information and experiences on food safety management, and to foster partnership alliances in support of capacity building. They help foster harmonization of ideas and creation of natural and sustainable networks amongst regulators and their systems." FAO, 124th Sess., Rome, Convening of Global and Regional Meetings of Food Safety Regulators (June 23-28, 2003), available at http:/www.fao.org/DOCREP/MEETING/006/Y9332e.HTM. As an example of the kind of discussions held at these meetings, see FAO \& WHO, Final Report of the FAO/WHO Regional Conference on Food Safety for Asia and the Pacific (May 24-27, 2004), available at http://www.fao.org/docrep/meeting/008/ad91le/ ad91 le00.htm.

${ }^{123}$ See generally VAN DER MEULEN \& VAN DER VELDE, supra note 76 , at $472-$ 80 (discussing the legal force of Codex standards).

${ }^{124}$ See generally POST, supra note 76. 
tion of the Codex process. How this will affect the usefulness of Codex as a forum for discussion and development of new concepts remains an open question.

\section{REGIONAL AND NATIONAL LEGAL RESPONSES TO FOOD SAFETY CRISES}

\section{A. EU Reform}

From the formation of the European Community in 1958 to the mid-1990s, European food law focused on reducing barriers to the creation of an integrated internal market for foods. ${ }^{125}$ The BSE and other food safety crises of the mid- to late 1990s changed this focus to one on maintaining public confidence in the safety of the food supply. ${ }^{126}$ The BSE crisis created public pressure on European governments for wholesale reform of food safety law in Europe and influenced the character of that reform. ${ }^{127}$ Because of the timing and the European states' influence in international trade negotiations, the BSE crisis likewise affected Codex norms and, through them, will influence food safety policy globally into the future. ${ }^{128}$

${ }^{125}$ From the 1960s through 1970 s, a central question for European food law was how to control the barriers to internal trade created by the diversity of national requirements on food content and safety. The first approach tried was creation of uniform European standards on food content and identity, somewhat like Codex standards on food content or American Society for Testing and Materials (ASTM) technical standards on products such as machine screws. This approach, sometimes referred to as "vertical" or "positive" harmonization, proved infeasible for use in European food markets because of the simple number and diversity of food products, and also culturally unacceptable because of diversity of food cultures across Europe. See VAN DER MEULEN \& VAN DER VELDE, supra note 76, at 230-31; see also Alberto Alemanno, Food Safety and the Single European Market, in WHAT'S THE BEEF?: THE CONTESTEd GovernanCE OF EUROPEAN FoOd SAFETY 237 (Christopher Ansell \& David Vogel eds., 2006) (offering an insightful perspective on the evolution of European food law). A series of European Court of Justice Cases in the 1970s created a new way forward. These culminated with the introduction of the principle of mutual recognition in Cassis de Dijon. See Case 120/78, Rewe-Zentral AG v. Bundesmonopolverwaltung für Branntwein, 1979 E.C.R. 649. Under the principle of mutual recognition, European Community states may not refuse entry of products produced and marketed in compliance with the law of another member state simply on the grounds that they do not comply with the law of the state refusing entry. As one commenter put it, "In essence, the Court's rule was that, within the context of the common market, what is good enough for consumers in one member state is good for consumers across the Community." VAN DER MEULEN \& VAN DER VELDE, supra note 76 , at 230-31.

\footnotetext{
126 VAN DER MEULEN \& VAN DER VELDE, supra note 76, at 229.

127 Debra Holland \& Helen Pope, EU Food Law and Policy 173 (2004).

${ }^{128}$ See FAO \& WHO, supra note 91 , at 71.
} 
The nature of BSE and the way both national and EU authorities managed the crisis had a significant impact on subsequent EU reforms. ${ }^{129}$ BSE is a fatal, neurodegenerative disease caused by prions, a newly identified disease agent. ${ }^{130}$ BSE was first identified in UK cattle in $1986 .^{131}$

Transmission among cattle was traced to the practice of feeding them animal offal and bone meal as a protein supplement. ${ }^{132}$ Britain banned this practice in $1988 .{ }^{133}$ By the time of its ban, the feeding practices were so widespread in the United Kingdom that they led to an epidemic with more than 180,000 diseased animals by $2004 .^{134}$

An official UK inquiry into the British government's handling of the BSE epidemic concluded that the government had misled the public for many years through a campaign of reassurance downplaying human health risks in order to prevent panic and protect the British beef industry. ${ }^{135}$ The report found that the British government had relied heavily on a 1989 study that hypothesized that BSE in cattle was related to the disease scrapie in sheep. ${ }^{136}$ Because scrapie has never been found to be transmissible to humans, the British government assumed that BSE also was not transmissible to humans. ${ }^{137}$

At a European level, as long as BSE remained solely an animal disease, the European Commission (EC) was required to act under the advice of the Standing Veterinary Committee (SVC) which was dominated by scientists appointed by the British government. Even though scientific evidence began to suggest that BSE was being

129 Ellen Vos, EU Food Safety Regulation in the Aftermath of the BSE Crisis, 23 J. CONSUMER POL'Y 227 (2000) (arguing that the BSE crisis marked a watershed in European food safety law and shaped the structure of reforms that followed it).

${ }^{130}$ BSE is caused by a prion, a form of protein that physically interacts with proteins in the host, deforming the way they fold. Prions and the mechanism through which they cause disease were only identified in the 1990s. See Stanley B. Prusiner, Molecular Biology of Prion Diseases, 252 SCIENCE 1515, 1515 (1991).

131 See Sebastian Kraphol, Risk Regulation in the Single Market $126-$ 36 (2008).

132 Tom Buerkle, U.K. Understated 'Mad Cow' ThreatReport Calls Officials to Task For Having Misled the Public, INT'L Herald TrIB., Oct. 27, 2000.

133 The Bovine Spongiform Encephalopathy Order, No. 1039 (1988) (Eng.).

134 Holland \& POPE, supra note 127, at 173.

135 Nicholas Phillips, The BSE Inquiry: Return to an Order of the Honourable the House of Commons Dated OCtOBer 2000 for the Report, EVIDENCE AND SuPPorting PAPERS OF THE INQUiRy INTO THE EMERGENCE AND IDENTIFICATION OF BOVINE SPONGIFORM ENCEPHALOPATHY (2000). For a summary see Buerkle, supra note 132.

136 Buerkle, supra note 132; see also Ortega Medina Report, infra note 143.

137 Buerkle, supra note 132. 
transmitted to humans, ${ }^{138}$ the government continued to maintain that this was not the case until, in March 1996, it announced that the best explanation for new variant cases of Creutzfeldt-Jakob disease (vCJD), which caused brain deterioration and death in humans, was exposure to beef from cattle infected with BSE. Public confidence in the UK Ministry of Agriculture, Fisheries and Food (MAFF) plummeted. ${ }^{139}$ Many people, including those in scientific and political circles, believed that the MAFF did not seek out or take seriously external scientific expertise on the relationship between BSE and human disease because it was also responsible for promoting agriculture. ${ }^{140}$ By the mid-1990s, many individual European governments were banning importation of British beef. ${ }^{141}$ Yet at an EC meeting held on March 25, 1996, the SVC maintained that existing regulations were adequate to control the disease. ${ }^{142}$ At the EC's insistence, however, the SVC finally voted to ban export of cattle and cattle products from the United Kingdom at the same meeting. In July 1996, the EU Parliament formed a Committee of Enquiry, which presented its report in early 1997 and found that the structure of EU food safety governance that allowed domination of decisions by a single member state, politicization of science, and lack of transparency all contributed to the inability of the EU to respond to the crisis quickly. ${ }^{143}$

The Committee of Enquiry report demonstrated the need for reform of Europe's food safety policy structure. Subsequent food

138 KRAPHOL, supra note 131 , at $127-29$. For details regarding the association between animal feed and BSE, see Buerkle, supra note 132.

139 "The conclusions presented to the British government by the SEAC prompted the announcement made by the British Health Secretary, on March 20, 1996. His speech before the House of Commons sent shockwaves throughout the world when he announced that there may exist a link between BSE and an apparent new strain of CJD. Media reaction to this news was widespread and at times hysterical causing beef purchases and consumption to plummet. Although there were earlier scares, none had the devastating effect of the recent one." ForEIGN AGRIC. SERV., U.S. DEP'T OF AGRIC., BSE ROCKS THE EU BEEF SECTOR (1996), http://www.fas.usda .gov/dlp2/circular/1996/96-11/bse.html.

${ }_{140}$ On May 16, 1990, British Secretary of State John Gummer appeared on British television eating a hamburger with his young daughter in an effort to assure the public of the safety of British beef. John Gummer: Beef Eater, BBC NEws, Oct. 11, 2000, http://news.bbc.co.uk/2/hi/uk_news/369625.stm.

${ }_{141}$ John Darnton, British Beef Sales Plunge as Germany and Italy Join Import Ban, N.Y. Times, Mar. 23, 1996, available at http:/www.nytimes.com/1996/03/23/ world/british-beef-sales-plunge-as-germany-and-italy-join-import-ban.html.

${ }^{142}$ KRAPHOL, supra note 131, at 129.

143 Report on Alleged Contraventions or Maladministration in the Implementation of Community Law in Relation to BSE, Without Prejudice to the Jurisdiction of the Community and National Courts, A4-0020/97/A (Feb. 7, 1997) [hereinafter Ortega Medina Report]. 
safety crises, including increased incidence of verotoxin-producing $E$. coli (VTEC) in European meat and dairy products, continuing public concern about genetically modified food, and black markets for diethylstilbestrol (DES) as a feed additive, all contributed to pressure for immediate action. ${ }^{144}$ The response to dioxin contamination of feed in Belgium in $\mathbf{2 0 0 0}$ demonstrated the need for better and faster communication about food crises among European national food authorities. ${ }^{145}$ Recommendations for structural change followed quickly in the form of a Green Paper in April 1997 and a White Paper on food safety in January $2000 .^{146}$

The White Paper lays out the EC's vision for reform of European food safety law and is a guide to subsequent legislative action. In writing it, the EC was driven by a need to "re-establish public confidence in its food supply." 147 The experience with BSE and subsequent animal feed crises created a focus on food safety policy extending from farm-to-table as a means of assuring that every link in the food supply chain protects consumer health. The EC was guided by five central principles: clearly defined food safety responsibilities for all actors in the food supply chain; traceability of food, feeds, and food ingredients to their sources; transparency and separation of scientific analysis from risk management to reduce the role of influence or corruption in food safety policy decisions; risk analysis as the framework for science-based policy; and the precautionary principle to guide risk management. ${ }^{148}$ Although the consumer's role in ensuring food safety was noted, the emphasis was placed on the production

144 VAN DER MEULEN \& VAN DER VELDE, supra note 76, at 238-39, 239 n.18892; HOLLAND \& POPE, supra note 127, at 173.

145 Raymond O'Rourke, EuRopean FoOd Law 9 (2005).

${ }^{146}$ Green papers are discussion papers published by the Commission on a specific policy area. Primarily, they are documents addressed to interested parties organizations and individuals - who are invited to participate in a process of consultation and debate. In some cases, they provide an impetus for subsequent legislation. See Commission Green Paper on the General Principles of Food Law in the European Union, COM (1997) 176 final (Apr. 30, 1997), http://europa.eu/bulletin/en/ $9704 / \mathrm{p} 103042 . \mathrm{htm}$. In contrast, white papers are documents containing proposals for Community action in a specific area. They sometimes follow a green paper published to launch a consultation process at European level. Whereas green papers set out a range of ideas presented for public discussion and debate, white papers contain an official set of proposals in specific policy areas and are used as vehicles for their development. Commission White Paper on Food Safety, COM (1999) 719 final (Jan. 12, 2000), http://eur-lex.europa.eu/LexUriServ/site/en/com/1999/com1999_0719en01 .pdf.

147 Commission White Paper on Food Safety, supra note 146.

148 Bente Halkier \& Lotte Holm, Shifting Responsibilities for Food Safety in Europe: An Introduction, 47 APPETITE 127, 128 (2006). 
and marketing side of the food supply chain. To avoid the politicization of science such as that which contributed to the BSE crisis, the White Paper placed responsibility for risk assessment and science advice with a new European Food Safety Authority and for risk management with the EC. In addition, the White Paper included a schedule for prompt consideration of eighty-four legislative and policy initiatives. The goals of this massive reform were, first, to update European food law and make it more coherent and comprehensive, and second, to strengthen enforcement and make it more consistent across countries. ${ }^{149}$

Ultimately, the decision to limit the European Food Safety Authority's function to providing scientific advice may have been driven by a broader concern about the democratic accountability of EU institutions and EC Treaty provisions that place legislative and management powers in the European Commission, European Parliament, and European Council. But concern for democratic accountability does not explain the White Paper's recommendation to separate risk assessment from risk management under European food safety law. This requirement is clearly related to protecting the integrity of scientific analysis and restoring public confidence in food safety governance. ${ }^{150}$

In subsequent years, the $\mathrm{EC}$ enacted most of the legislative agenda recommended in the White Paper, much in the form of regulations rather than directives. ${ }^{151}$ In January 2002, the European Parliament and Council adopted Regulation 178/2002, the General Food Law (GFL). As a regulation, it was immediately binding on all EU member states. ${ }^{152}$ Compared with its predecessors, the GFL places greater emphasis on horizontal regulations, which set general principles ap-

149 VAN DER MEULEN \& VAN DER VELDE, supra note 76, at 244-45.

150 See, e.g., Marion Dreyer et al., Institutional Re-Arrangements in European Food Safety Governance: A Comparative Perspective, in FoOd SAFETY REgulation in Europe: A Comparative Institutional ANalysis 9, 16 (Ellen Vos \& Frank Wendler eds., 2006).

151 Under the EC Treaty, "[a] regulation shall have general application. It shall be binding in its entirety and directly applicable to all Member States." In contrast, "A directive shall be binding, as to the result to be achieved, upon each Member State to which it is addressed, but shall leave to the national authorities the choice of form and methods." Treaty Establishing the European Community, Nov. 10, 1997, 1997 O.J. (C 321 ) art. 249.

152 Under the EC Treaty, "a regulation shall have general application. It shall be binding in its entirety and directly applicable to all Member States." In contrast, "A directive shall be binding, as to the result to be achieve, upon each member state to which it is addressed, but shall leave to the national authorities the choice of form and methods." See id. 
plicable to all foodstuffs, rather than on vertical regulations governing specific products. ${ }^{153}$

It also makes greater use of regulations that set objectives to be achieved rather than govern the means of achieving them and relies less on directives resulting in greater centralization of food safety authority. ${ }^{154}$ The GFL lays out basic principles to guide subsequent European food safety legislation and established the European Food Safety Authority and the Rapid Alert System. The system developed under the GFL is a three-legged stool resting on an integrated farm-totable system of food safety responsibilities and enforcement, a modern system of monitoring and communication that allows for rapid action if problems arise, and protection of the integrity of scientific analysis on which policy decisions rely. Like the SPS Agreement, which was negotiated at the same time, the GFL seeks to implement a farm-totable, preventive system of food safety policy based on scientific data and risk analysis. The law requires use of HACCP plans to make certain that preventive controls are used. ${ }^{155}$ The GFL's goal is to ensure "a high level of protection of human health and consumers' interests in relation to food." These interests include employing fair trade practices, maintaining the diversity of European food supply, including traditional products, promoting an integrated European market, and preventing fraud, adulteration, and deceptive practices. ${ }^{156}$

The GFL provides one example of what a farm-to-table approach to food safety control can look like. "Food and feed business operators at all stages of production, processing and distribution" are responsible for compliance with food law, including the GFL requirement that "food shall not be placed on the market if it is unsafe." 157 In determining whether food is unsafe, enforcement agencies and the European Community Court should take into account "normal conditions of production, processing and distribution and use," as well as "information on the label, or other information generally available to the consumer concerning the avoidance of specific adverse health

${ }^{153}$ Foreign Agric. Serv., U.S. Mission to the European Union, Harmonization of Food Law in the European Union, http://www. fas.usda.gov/posthome/useu/ harmonization.html (last visited May 3, 2010). By 2007, the EU had adopted regulations on GMOs, food hygiene, and food contact materials, as well as rules for coordination of food safety law enforcement across Europe. The EC is currently working on modernization of food labeling, pesticides, and food additive legislation, and on legislation to govern novel foods. Dreyer \& Renn, supra note 48, at 250 diagram 7.7.

154 VAN DER MEULEN \& VAN DER VELDE, supra note 76, at $249 \mathrm{n} .216$

155 Regulation 178/2002, art. 14, 2002 O.J. (L 31) 1, 14 (EC).

156 Id. at $1,9,12,13$.

${ }^{157}$ Id. at $1,14,16$. 
effects from a particular food or category of foods." 158 Food is unsafe if it causes short- or long-term health effects to either the consumer or subsequent generations, taking into account "probable cumulative toxic effects" and the health sensitivities of subpopulations if the food is marketed specifically to certain subpopulations, such as infants.

The GFL establishes an EU-wide integrated system of monitoring and enforcement. Although business operators have the primary responsibility to keep unsafe food out of the market, national governments are responsible for creating and maintaining the inspection and enforcement systems needed to ensure compliance with EU law, both for domestic production, processing, and marketing and for imports. ${ }^{159}$ The EU Food and Veterinary Office audits food safety systems in both EU member states and countries that export to the EU. ${ }^{160}$ Food businesses are required to inform relevant authorities of the existence of their establishments and to cooperate with those authorities. ${ }^{161}$ If food or feed operators have reason to doubt the safety of food or feed, they must withdraw the product from the market, and if it has already reach consumers, the operators must inform the affected consumers and recall the unsafe product. ${ }^{162}$ The general public is also to have access to information on the product recalled, the nature of the risk, and the control measures taken. ${ }^{163}$

A core element of the new law is traceability of foods and sharing of information on potential hazards across Europe. All food and feed businesses must have the ability to trace their products one step forward and back in the supply chain and to inform their national food authority if they have reason to believe that they have put unsafe food into the market. ${ }^{164}$ A centralized EU-level tracking system - Trace Control and Expert System (TRACES) - tracks the movement of livestock in the EU from origin to slaughter. ${ }^{165}$ Regulation 178/2002

${ }^{158}$ Id. at $1,14$.

159 Id. at $1,16$.

160 FoOD SAFETY, supra note 53, at 15.

161 Commission Regulation 852/2004, 2004 O.J. (L 226) 3, 8 (EC).

162 Regulation 178/2002, supra note 155 , at $1,16,17$. Canada also makes product recall mandatory. See FoOD SAFETY, supra note 53, at 28. Compare with the United States, where the FDA has voluntary, not mandatory, recall authority. Although many countries have mandatory recall authority, it has seldom been necessary to use it, because the knowledge that it could be used has generally been enough to secure cooperation of businesses with food authorities. Id.

${ }^{163}$ Holland \& POPE, supra note 127 , at 30 . The United States has a similar system of posting information on product recalls on the U.S. FDA website. FDA, RECalls, MarKeT WITHDRAws, \& SAFETy AlerTS, http:/www.fda.gov/safety/ recalls/default.htm (last visited May. 3, 2010).

${ }_{164}$ Regulation 178/2002, supra note 155 , at $1,16$.

165 See FoOd SAFETY, supra note 53, at 50-51. 
establishes a Europe-wide Rapid Alert System, a communication network managed by the European Food Safety Authority responsible for disseminating information about serious threats to health from food or feed to all EU member states. To prevent circumvention of import controls, when a European port of entry refuses entry of a shipment of food, it is also required to notify all other European ports of entry of the refusal. ${ }^{166}$ The system quickly proved its effectiveness in contributing to the rapid control of chloramphenicol in honey in $2004 .^{167}$

The GFL is explicit that "food law shall be based on risk analysis." ${ }^{168}$ Political and food industry influence on scientific analysis in Britain was at the bottom of the BSE scandal and the resulting crisis in public confidence. To protect risk analysis from political influence, the GFL institutionally separates responsibility for risk assessment and risk management and even separates the responsible bodies geographically. Article 22 of the GFL creates the European Food Safety Agency (EFSA) as an independent entity responsible for providing scientific advice, risk assessment, and technical support for policy. EFSA is headquartered in Parma, Italy. Risk management decisions are the domain of the European Commission, European Parliament, and European Council. These bodies, as well as member states, may ask the EFSA for a scientific opinion. The EFSA may also initiate investigations and analyses on its own initiative. ${ }^{169}$ Scientific integrity is further guarded by requirements for disclosure of conflicts of interest by scientists working with the EFSA and by requirements of public meetings and timely publication of agendas, minutes, and opinions. ${ }^{170}$ The EFSA has eight core responsibilities: providing scientific opinions; identifying and addressing divergent scientific opinions, particularly among European and national food safety agencies; providing scientific and technical assistance at the request of the European Commission and member states; independently commissioning scientific studies needed to perform its mission; developing systems to monitor emerging risks and collect relevant data assessing the prevalence of foodborne hazards; facilitating scientific cooperation related to food safety risk assessment in the EU; promoting communication and networking among European organizations relevant to risk as-

166 See id. at 53.

167 Michael Durham, A Bitter Taste of Honey, GuARdian, July 21, 2004, at 16, available at http://www.guardian.co.uk/news/2004/jul/21/food.foodanddrink (last visited May 3, 2010).

168 Regulation 178/2002, supra note 155, at 1, 12.

169 Holland \& POPE, supra note 127, at 29.

170 Regulation $178 / 2002$, supra note 155 , at $1,28$. 
sessment, particularly to exposure and the prevalence of hazards; and contributing to risk communication for consumers.

The EFSA is governed by a management board of fourteen members appointed by the European Council in consultation with the European Parliament from a list the European Commission proposes. Four of the members must have experience working for organizations that represent consumers or other interests in the food chain. The board reviews and approves the EFSA's work program and budget each year to ensure that it carries out its legislative mission. An executive director appointed by the board from a list of candidates proposed by the Commission is responsible for administering the EFSA. The executive director works with the Commission to develop a proposed EFSA work program and is assisted by an advisory forum of representatives of science agencies from member states. The advisory forum is intended to promote communication across Europe, avoid duplication of scientific effort, and better identify emerging issues. Panels of independent scientific experts are responsible for providing the scientific opinions of the EFSA. ${ }^{171}$ A scientific committee, made up of the chairs of the scientific panels and six independent scientific experts not on any of the panels, is responsible for the coordination needed to ensure consistency in work procedures across the panels. $^{172}$

Finally, risk management decisions reached by the European Commission, Parliament, Council, and member states are to take into account the results of risk assessments and scientific advice, but may also consider factors such as societal, economic, traditional, ethical, and environmental concerns, as well as the feasibility of controls. Where a risk assessment has been conducted and scientific uncertainty persists because of inadequate data, the precautionary principle may be invoked by challengers, and provisional measures may ultimately be taken to protect public health pending more complete scientific information. ${ }^{173}$

The EFSA is not the final arbiter of scientific opinion in the EU, but it is expected to play an increasingly central role. It is also anticipated that conflict will arise over scientific judgment between the EFSA and member states. National governments are engaged in scientific analysis and risk analysis as well. The EFSA has responsibility for maintaining communication among these bodies and identi-

171 Id. at 1, 22-24.

172 VAN DER MEULEN \& VAN DER VELDE, supra note 76, at 207-08.

${ }^{173}$ Regulation 178/2002, supra note 155, at 1, 12-13. 
fying divergence in scientific opinion. ${ }^{174}$ It remains to be seen how the European Community courts will treat EFSA scientific opinions. In Pfizer Animal Health, the EC court ruled that, though national food safety authorities are not required to seek out an EFSA scientific opinion in developing national rules, they are required to take into account existing EFSA risk assessments. ${ }^{175}$ The GFL also creates a general obligation on the part of firms to ensure that the food they market is safe. ${ }^{176}$ Under Article 14(1), marketing of unsafe food is therefore both a breach of an implied warranty of safety and a breach of general product liability law. ${ }^{177}$ National courts are not obliged to consult the EFSA in deciding cases brought to enforce this provision, but they are likely to look to its scientific opinion in reaching their opinions. Alemanno, author of a leading treatise on European food safety law, argues that the courts would likely view an EFSA opinion that a product or practice is unsafe as creating a strong presumption against safety. ${ }^{178}$

Each EU member state is responsible for disease surveillance and outbreak response within its own borders, for informing the European Centre for Disease Prevention and Control (ECDC) of outbreaks that may affect other member states, and for cooperating with other member states and EU-level offices in responding to multicountry outbreaks. The ECDC manages Enter-net, a computerized international intestinal (enteric) disease surveillance network. All EU member states, Norway, Switzerland, Australia, Canada, South Africa, and Japan participate in this network. ${ }^{179}$

Will this system work for Europe? Several studies have examined the European food safety policy reform movement of the 1990s from the perspectives of law, political science, public administration, and sociology. ${ }^{180}$ They conclude that the system is likely to result in conflicts in scientific opinion. But given Europe's diversity in culinary culture, it allows for diversity of judgment about what constitutes acceptable risk. As Alemanno writes:

A claim by a domestic food authority that a certain good is safe or unsafe is likely to involve not only an assertion about

${ }^{174}$ Id. at $1,25$.

175 See Alemanno, supra note 125 , at 251.

176 Regulation 178/2002, supra note 155, at 1, 14-15.

177 Id.

178 See Alemanno, supra note 125 , at 251.

179 See Food SAFETY, supra note 53, at 56.

180 Halkier \& Holm, supra note 148; Alberto Alemanno, Trade In Food: REGULATORY AND JUDICIAL APPROACHES IN THE EC AND THE WTO (2007); and VAN DER MEULEN \& VAN DER VELDE, supra note 76. 
science, but also the willingness of this country to bear or not bear the level of risk considered acceptable in order to continue or reject a certain local tradition. In contrast, the assertion made at the EC level about the safety of a product to be marketed throughout the $\mathrm{EU}$ is both a claim about its risk component and a political claim aimed at favoring economic integration and free trade within Europe. ${ }^{181}$

Alemanno maintains that it is appropriate that the European courts and not the EFSA resolve conflicts arising between national and EFSA scientific opinion. ${ }^{182}$

Van der Meulen and van der Velde have examined EFSA opinions and concluded that they all have been related to narrow decisions on particular products or food safety targets. ${ }^{183}$ In their view, risk assessment is informing administrative decisions rather than policy direction. They argue that the institutional isolation of risk assessment and scientific analysis from risk management may actually result in risk assessments being less central to risk management or food safety policy decisions. ${ }^{184}$ Yet in certain instances, European policy appears to be risk-based. For example, member states base the intensity of their import inspections on the inherent riskiness of the product being imported. Factors that come into play in their determination of product risk include the nature of the food (e.g., whether it is of animal or nonanimal origin), the quantity imported, and the sanitary and phytosanitary conditions in the area from which it is imported. ${ }^{185}$

\section{B. National Responses}

National governments of many OECD nations have undergone major food safety legislative reform since the $1990 \mathrm{~s}$. ${ }^{186}$ Within the EU, individual countries responded both to the BSE crisis and to EUlevel reforms. ${ }^{187}$ Reforms in Australia, Canada, Denmark, and New

181 Alemanno, supra note 125, at 254.

182 See id.

183 VAN DER MEULEN \& VAN DER VELDE, supra note 76, at 269.

184 ld.

185 See generally FOOD SAFETY, supra note 53, at 6, 11.

186 The U.S. Government Accountability Office recently reviewed these reform efforts to help inform congressional deliberations on import safety and reorganization of federal food safety authority in the United States. Id. at 2-3.

187 Vos and Wendler report on an extensive multi-institutional effort to provide an empirical comparison of institutional reform efforts in five European countries: Hungary, Sweden, the United Kingdom, France, and Germany. See FoOD SaFETy Regulation IN EUROPE: A COMPaRative InStitutional ANAlysis (Ellen Vos \& Frank Wendler eds., 2006). 
Zealand were largely motivated by a desire to enhance the efficiency of public administration by eliminating overlapping authorities, focusing resources on high-risk areas, and redressing inconsistencies in enforcement. ${ }^{188}$ New Zealand's reform was part of a reorganization of the entire government in an effort to increase efficiency and enhance its competitiveness in world trade. ${ }^{189}$

Preventive controls were one of the earliest elements of the current generation of food safety policy to be adopted. The commitment to prevention includes a general principle that policy should aim to prevent foodborne illness rather than responding to it and containing its damage. It also includes a specific reliance on HACCP plans as a preventive management tool. This reliance on HACCP is seen its central role in CODEX food codes since 1995. ${ }^{190}$ By the mid-1990s, the European Union was requiring food companies to operate under HACCP plans. ${ }^{191}$ The United States promulgated mandatory HACCP regulations for seafood, meat and poultry, and juice processing at the same time. New Zealand, Australia, and Canada were also early adopters of HACCP. ${ }^{192}$ FAO, through Codex regional committees, has been working with developing countries to encourage adoption of appropriate HACCP policies. ${ }^{193}$

EU member states are under treaty obligation to bring their laws into conformance with the General Food Law and related directives. But the GFL gives member states latitude in how they implement EU obligations. A few examples provide a sense of how EU member states are adapting GFL requirements to their national governance structures.

In the United Kingdom, BSE created a profound crisis in confidence in national food safety policy. ${ }^{194}$ UK government investigations pointed to the dominance of agricultural interests, lack of governmental transparency, and fragmentation of food safety responsibility among multiple agencies as key factors in the crisis. ${ }^{195}$ In 2000 , food safety authority was consolidated under an independent agency, the UK Food Standards Agency (FSA). The FSA is also the United

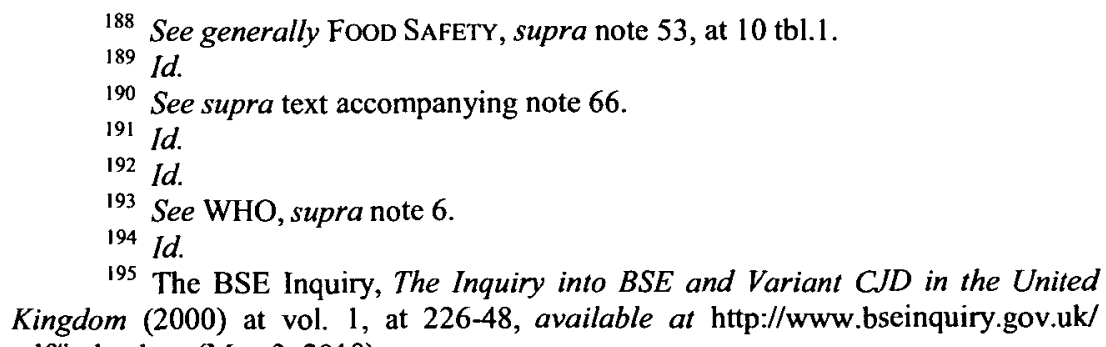

195 The BSE Inquiry, The Inquiry into BSE and Variant CJD in the United Kingdom (2000) at vol. 1, at 226-48, available at http://www.bseinquiry.gov.uk/ pdf/index.htm (May 3, 2010). 
Kingdom's "competent authority" under EU GFL responsible for implementation of EU food and feed law. ${ }^{196}$ In conformance with the GFL, the FSA has farm-to-table responsibility for food safety. The FSA's mandate is to protect " public health from risks which may arise in connection with the consumption of food (including risks caused by the way in which it is produced or supplied) and otherwise to protect the interests of consumers in relation to food." ${ }^{197}$ This emphasis on public health and consumers responds to concern about the role agricultural interests played in the BSE crisis. The FSA relies on risk analysis in developing regulations, setting strategic planning priorities, and designing inspection regimes. ${ }^{198}$ The integrity of risk assessment is protected by keeping management responsibility within the agency and having risk assessments conducted by advisory committees. ${ }^{199}$

Denmark revised its food safety law in 2005, adopting a risk management system that extends from farm-to-table. ${ }^{200}$ It uses risk classification of food establishments as a basis for determining the frequency of inspections. ${ }^{201}$ Following EU requirements, Denmark separates risk management from risk assessment. The Food and Veterinary Administration, a part of the Ministry of Food, Agriculture and Fisheries, is vested with management responsibilities. Risk assessments are conducted by the Technical University of Denmark. ${ }^{202}$

In 1996, Denmark launched an aggressive set of farm-to-table programs of Salmonella control in poultry and hogs. ${ }^{203}$ This set of programs is one of the most aggressive examples of what may be involved in farm-to-table risk management of foodborne disease agents. The goal of the programs was reduction of the prevalence of Salmonella in poultry flocks and hog herds and the human incidence of foodborne salmonellosis in Denmark. The programs involve extensive testing of animal feed, flocks and herds, carcasses, and meat for Salmonella using genotyping, as well as intensive surveillance and genetic characterization of human cases of salmonellosis. Genetic

196 Food Standards Act, 1999, c. 28 (U.K.).

$197 I d$. at $\S 1(2)$ (emphasis added).

$198 I d$. at $\S 23(2)$.

199 Interview with Derrick Jones, Chief Economist, UK Food Standards Agency (Sept. 3, 2009).

200 Stuart A. Slorach, Food Safety Risk Management in New Zealand 31 (2008), http://www.nzfsa.govt.nz/about-us/risk-management-framework-review/ slorach-report-nzfsa-risk-management.pdf.

201 Id. at 32.

202 Id.

203 Flemming Bager \& Christian Halgaard, Salmonella Control Programmes in Denmark (2002), http://www.adiveter.com/ftp/articles/articulol057.pdf. 
fingerprinting coupled with records on feed and animal movement allow Danish authorities to trace positive Salmonella tests back through the supply chain all the way to feed suppliers if necessary. ${ }^{204}$ The program has led to a significant reduction in both the prevalence of Salmonella on Danish farms and the incidence of salmonellosis human disease. The program was subsidized by the Danish government and justified on the bases of both human health concerns and export promotion. The small scale of Danish agriculture as well as the existence of a strong farm cooperative system that had a history of involvement in zoonotic disease eradication contributed to the acceptability and success of the program. ${ }^{205}$ These institutional conditions may not be common or easily reproducible elsewhere.

Ireland moved to correct both a perception of regulatory capture by industry interests and fragmentation by creating the Food Safety Authority of Ireland (FSAI) in 1998, a small agency that functions largely through contracts. The Department of Agriculture and Food is contracted to enforce food safety rules governing establishments exporting foods of animal origin or importing products of animal origin. The Health and Safety Executive is contracted to enforce food safety requirements in food establishments and on imports. The FSAI relies on a scientific committee of food safety experts across Ireland to conduct risk assessments, develop risk profiles, and provide scientific advice to be used in risk management decisions. ${ }^{206}$

Sweden is looking into creating a single foòd safety agency with farm-to-table responsibility to replace the three agencies now in place. Currently, the National Food Administration (NFA) is responsible for import controls and for setting and enforcing rules governing large meat packers and food processors. It uses a risk classification system to determine the frequency of inspections and set inspection fees. The National Fisheries Board and the Swedish Board of Agriculture are responsible for primary production, and municipalities for overseeing marketing and small producers. Both risk assessment and risk management are conducted within NFA, but by different departments. NFA also relies heavily on outside scientific advisors. ${ }^{207}$

Outside the EU, different economic and political forces are driving reform, though they are influenced by developments in the EU through Codex. In the mid-1990s, Australia and New Zealand agreed to establish a joint food-standard-setting system to reduce industry

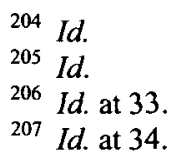


costs and regulatory barriers to trade. ${ }^{208}$ Reforms to this system in the early 2000s were motivated by a desire to reduce regulatory burden. ${ }^{209}$ Additional reforms in the mid-2000s brought the system into greater conformance with international norms, for example, by separating the risk assessment and risk management and adopting a farm-to-table approach. $^{210}$

The Joint Food Standards Treaty between Australia and New Zealand adopts a joint system for development and promulgation of food standards and information sharing. Under this regime, the Food Standards Australia New Zealand (FSANZ) has responsibility for administering the food standards code and developing food standards through a process of public consultation. The standards are to be based on rigorous science and risk assessment. ${ }^{211}$ The Australia and New Zealand Food Regulation Ministerial Council has final authority for approval or rejection of these standards and is directed to balance the objectives of ensuring public health and safety and providing food efficiently with minimal regulatory burden. Within Australia's federal system, state-level food standards were harmonized under a 1991 agreement. Australia and New Zealand are working to harmonize standards in many areas of food safety.

The New Zealand and Australian governments are responsible for setting standards in areas covered by joint standards and implementing and enforcing jointly set standards. The New Zealand Food Safety Authority has also developed its own capacity to assess and manage risk using a framework that reflects close coordination with WHO/FAO and Codex. ${ }^{212}$ Unlike some European authorities, New Zealand does not institutionally isolate food safety administration from promotion of agriculture. Slorach conducted an extensive review of the New Zealand framework, including its application to risk assessment and management of Campylobacter in poultry, aspartame

${ }^{208}$ Food Standards Austl. New Zealand, About FSANZ, http://www.food standards.gov.au/aboutfsanz/ (last visited May 3, 2010).

209 See id.

210 See generally SLORACH, supra note 200, at 27; New Zealand Food Safety Authority, New Zealand's Food Safety Risk Management Framework (2010), http://www.nzfsa.govt.nz/about-us/RMF_full_document_-_11604_NZFSA_Risk _Management_Framework_3.1.pdf; WHO \& FAO, Food Safety Risk Analysis: A $\bar{G}$ uide for National Food Safety Authorities, FAO Food and Nutrition Paper 87 (2006), available at http://www.who.int/foodsafety/publications/micro/riskanalysis06 .pdf; FAO \& WHO, Codex Alimentarius Commission Procedural Manual (2008); Codex Alimentarius Comm'n, Principles and Guidelines for the Conduct of Microbial Risk Management, at 17, CAC/GL-63 (2007).

211 See SLORACH, supra note 200, at 25-31.

212 See Food Standards Austl. New Zealand, supra note 208. 
as a food additive, import safety, mercury in fish, and public concern about milk safety compared with actions taken in Denmark, Ireland, and Sweden. ${ }^{213} \mathrm{He}$ argues that because New Zealand depends so heavily on high-value agricultural exports, food safety is as much an economic as a domestic health concern. ${ }^{214}$ New Zealand uses a riskbased approach to the inspection of imports. Risk is defined on the basis of safety characteristics of food products and other factors. ${ }^{215}$ New Zealand is moving toward greater reliance on verification of food safety practices by the importer and less reliance on border inspection for lower-risk foods.

A major goal of Canadian food safety reform has been reducing the cost of government, though recent, well-publicized outbreaks may affect public confidence in the safety of the food supply. ${ }^{216}$ The Canadian Food Inspection Agency (CFIA) was created in 1997 as an independent agency that reports to the Minister of Agriculture and Agri-Food. ${ }^{217}$ This action consolidated food safety responsibilities that had previously been spread among four federal government agencies. $^{218}$ The Public Health Agency of Canada is responsible for disease surveillance and participates in outbreak response. ${ }^{219}$ The Food Directorate, an independent office within Health Canada, is responsible for conducting risk assessments for both Health Canada and CFIA. ${ }^{220}$ Canada separates standard setting from enforcement with standard setting conducted by Health Canada and enforcement by the CFIA. To provide a check on the apparent conflict of interest posed

213 See SLORACH, supra note 200, at 44-61.

214 Id. at 35.

215 Id

216 See U.S. Gov't Accountability OfFice, Experience of SEven Countries in CONSOldidating Their Food SAFETy AgEnCiEs (2005) (discussing the reasons different nations formed unified food safety agencies). CNNHealth.com, Canada Links Toronto Plant to Deadly Listeriosis Outbreak (Aug. 24, 2008), http:/www.cnn.com/2008/HEALTH/08/24/listeria.outbreak/index.html.

${ }^{217}$ Canadian Food Inspection Agency, Science and Regulation . . Working Together for Canadians, http://www.inspection.gc.ca/english/agen/broch/broche.pdf (last visited May 3, 2010).

218 U.S. Gov'T ACCOUNTABILITY OFFICE, supra note 216.

219 The Public Health Agency of Canada, like the Centers for Disease Control and Prevention in the United States, is responsible for disease surveillance and communications regarding the status of diseases in Canada. See Pub. Health Agency of Can., About the Agency, http://www.phac-aspc.gc.ca/about_apropos/index-eng.php (last visited May 3, 2010).

${ }^{220}$ See Health Can., Food-Related Health Risk Assessment, http://www.hc-sc .gc.ca/fn-an/securit/chem-chim/food_risk-risq_alim-eng.php (last visited May 3, 2010). Health Canada manages the Canadian health care system and monitors health risks associated with a wide range of consumer products. See Health Can., Food and Nutrition, http://www.hc-sc.gc.ca/fn-an/index-eng.php (last visited May 3, 2010). 
by having the agency responsible for promoting agriculture also enforcing food safety laws, Health Canada is also charged with evaluating the effectiveness of CFIA's enforcement programs. ${ }^{221}$ Since 2005, the Canadian Border Services Agency (CBSA) has been responsible for initial inspection of food imports. CFIA conducts follow-up inspections when CBSA finds questionable shipments. Approximately two percent of food shipments and the majority of livestock shipments are inspected by both CBSA and CFIA. ${ }^{22}$

Current Canadian food safety policy and planning have many elements that flow from Codex and are common to other national plans. The Canadian Food and Consumer Safety Action Plan (FCSAP) calls for a strengthening of a preventive approach to food safety regulation relying on HACCP and identification of high-risk foods. Canada currently requires HACCP plans of registered facilities producing meat, meat products, and fish and seafood products. ${ }^{223}$ Although the FCSAP does not call for on-farm regulation, it does take on-farm food safety controls into account in determining "areas of highest risk." 224 It uses risk as a criterion for targeting enhanced oversight of imports and determining priorities in retail establishment inspection, and it looks to risk assessments to help identify high-risk products. ${ }^{25}$ The FCSAP also includes strengthening firm-level record-keeping requirements for use in tracing products should a problem arise. ${ }^{226}$ Canada already requires that cattle and sheep bear a registered ID tag before they can leave their farm. The Canadian Cat-

${ }^{221}$ See Health Can., Food-Related Health Risk Assessment, http://www.hc-sc .gc.ca/fn-an/securit/chem-chim/food_risk-risq_alim-eng.php.

${ }^{222}$ See FoOD SAFETY, supra note 53 (for a more a more general treatment of Canada's food import inspection program).

223 See Food Dev. Ctr., HACCP \& Regulatory, http://www.gov.mb.cal agriculture/fdc/fdc04s06.html (last visited May 3, 2010).

${ }^{224}$ Health Can., Health Canada's Regulatory Modernization Strategy for Food and Nutrition, http://www.hc-sc.gc.ca/fn-an/pubs/rm_strat_mr-eng.php (last visited May 3, 2010).

${ }^{225}$ Id.; see also Can. Food Inspection Agency, Canada Has a Robust RiskBased Import Control Program, http://www.inspection.gc.ca/english/fssa/concen/ specif/vegprofse.shtml (last visited May 3, 2010) (explaining the factors the government of Canada considers in deciding whether a product is high-risk); Health Can., Risk Categorization Model for Food Retail/Food Service Establishments - Second Edition, http://www.hc-sc.gc.ca/ahc-asc/pubs/hpfb-dgpsa/ fd-da/risk_categorization-categorisation_risques03-eng.php (last visited May 3, 2010) (describing criteria used to determine the riskiness of food retail establishments in considering inspection priorities.

226 See Env'T Can., Formative Evaluation of the Federal Contaminated Sites action Plan: Final Evaluation Report (2009), http://www .ec.gc.ca/doc/ae-ve/2008-09/997/es_eng.html. 
tle Identification Agency maintains a database of these registrations. $^{227}$ Canadian provinces are moving toward traceability requirements for food crops as well as livestock. ${ }^{228}$

Japan depends heavily on food imports. In recent years, it has adopted a risk-based approach to import controls. Most food imports are randomly inspected, and all lots of products deemed to have a high probability of violation are inspected. Japan bases this plan on the likelihood of violation as affected by food, firm history, and conditions in exporting countries. Priorities for monitoring food imports are revised annually in response to changes in risk profiles. ${ }^{229}$ Ordinary, random import inspections are free in Japan, but importers must pay for enhanced inspections as well as for violations of import standards. This has led many Japanese importers to require testing certification from exporters. ${ }^{230}$ In the case of serious import violations, the violators' names are posted on the Ministry of Health, Labor, and Welfare website. $^{231}$

In many respects, the United States led the way into the current generation of food safety policy reform. Its efforts were motivated by serious outbreaks of foodborne illness in the 1990s. ${ }^{232}$ As discussed above in Section II of this paper, the United States drew on a range of tools developed for environmental policy and even space programs. Both the FDA and the U.S. Department of Agriculture (USDA) began reorienting their food-processing rules around HACCP in the mid 1990 s. $^{233}$ In general, industry and consumer groups have been sup-

227 See Can. Food Inspection Agency, Traceability in Canada, http://www .inspection.gc.ca/english/anima/trac/traccane.shtml (last visited May 3, 2010).

228 See Ontrace, Traceability Backgrounder, http://www.ontraceagrifood.com/ documents/Traceability\%20Bkgder-Apr\%2007.pdf (last visited May 3, 2010).

229 See Foon SAFETY, supra note 53, at 74-76.

$230 \mathrm{Id}$

231 Id.

232 See Golan ET AL., supra note 5.

233 Nat'l Advisory Comm. on Microbiological Criteria for Foods, U.S. Dep't. of Agric., Hazard Analysis and Critical Control Point System (1989); Nat'l Advisory Comm. on Microbiological Criteria for Foods, Hazard Analysis and Critical Control Point System, 16 INT'L J. FoOd MiCrobiology 1, 2 (1992) (expanding upon the Committee's 1989 HACCP document by emphasizing the concept of prevention, incorporating a decision tree to identify critical control points, and providing a more detailed explanation of the application of HACCP principles; Nat'l Advisory Comm. on Microbiological Criteria for Foods, Generic HACCP for Raw Beef, 10 FoOD MICROBIOLOGY 449, 449 (1993) (adopting new practices and procedures for beef slaughter and processing in light of new technologies); Nat'l Advisory Comm. on Microbiological Criteria for Foods, The Role of Regulatory Agencies and Industry in HACCP, INT'L J. FoOd MiCRobiology 187, $187-95$ (1994); Nat'l Advisory Comm. on Microbiological Criteria for Foods, Hazard Analysis and Critical Control Point Principles and Application Guidelines, 61 J. FOOD ProteCtion 1249, 1249 (1998) 
portive of HACCP's adoption, though both consumer groups and the GAO have insisted that HACCP needs to be tied to performance standards, like the microbiological criteria adopted in the EU. ${ }^{234}$

HACCP was one of the first of many steps the United States has taken toward more risk-based food safety management. ${ }^{235}$ Throughout the 1990s and 2000s, substantial technical and policy expertise in food safety was directed at adapting risk analysis methods and frameworks to microbiological hazards in foods. Much of the scientific effort was focused on developing microbiological risk assessment. ${ }^{236}$ In recent years, both the FDA and USDA have been using risk profiling to focus inspection resources and increase their effectiveness. ${ }^{237}$ With recent import problems, the FDA has been looking toward more risk-based approaches to managing import safety. ${ }^{238}$ In the United States, responsibility for risk assessment and risk management generally lies within a single agency, but responsibility for each of the two areas is assigned to different work teams or offices within the agency with interaction to help ensure that risk assessment endpoints are appropriate for risk management purposes. The United States has also invested in improvements in disease monitoring to provide the information basis for risk-based targeting of policy by federal and state government - most importantly through development of FoodNet, a nationwide active surveillance system, and PulseNet, which uses genetic fingerprinting in tracing the source of outbreaks. ${ }^{239}$

Given the central role U.S. scientists and technical experts have played in the development of FAO/WHO guidance, coupled with the integration of Codex guidelines into the SPS Agreement, it is likely that the United States will continue to move toward adoption of inter-

(endorsing HACCP as an effective and rational means of assuring food safety from harvest to consumption).

234 HOLLAND \& POPE, supra note 127.

235 For an accessible, but comprehensive introduction to U.S. food safety law, see Neal D. Fortin, Food Regulation: Law, Science, Policy, and Practice (2009).

236 See Post, supra note 76, at $152-58$ for a brief history and analysis.

237 Food Safety \& Inspection Serv., U.S. Dep't of Agric., Risk-Based Inspection Questions \& Answers (2007), http://www.fsis.usda.gov/PDF/RBI_Q\&_A 022007.pdf; see Food Protection Plan and Import Safety Action Plan: Hearing $\bar{b}$ efore the Subcomm. on Oversight and Investigations of the H. Comm. on Energy and Commerce, 110th Cong. (2007) (statement of David Acheson, Assistant Comm'r for Food Protection of the FDA).

${ }^{238}$ Food Protection Plan and Import Safety Action Plan, supra note 237.

239 Ctrs. for Disease Control \& Prevention, Dep't Health \& Human Servs., CDC FoodNet -Foodborne Diseases Active Surveillance Network (Apr. 28, 2009), http://www.cdc.gov/FoodNet/; Ctrs. for Disease Control \& Prevention, Dep't Health \& Human Servs., CDC PulseNet (Apr. 28, 2009), http://www.cdc.gov/pulsenet/. 
national norms, whether through statutory or administrative law or through government-facilitated industry action, such as marketing orders. ${ }^{240}$ The United States clearly sees international cooperation on food safety as not only a means of protecting its trade interests, but also, more fundamentally, an essential element in protecting the safety of the U.S. food supply. In addition to its direct involvement with the Codex committees, the United Sates is engaged in other multilateral consultations. For example, the Quadrilateral Group, provides a forum for food safety experts from Australia, Canada, the United States, and New Zealand to discuss emerging issues and best-practice standards as they affect the four countries and offers support for shared interests at Codex sessions. ${ }^{241}$

Until recently, the United States has been moving toward a farmto-table approach to food safety on a more case-by-case basis than in Europe, often in response to food safety incidents. After outbreaks of shiga-toxin $E$. coli in leafy greens in 2006 , which resulted in three deaths and 200 illnesses, produce growers and regulators worked together to develop non-binding guidelines for producers of ready-to-

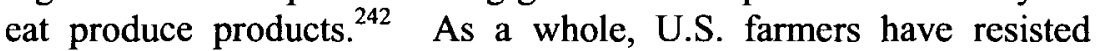
on-farm regulation. As farms consolidate and become more industria-

240 Marketing orders are a system of producer-initiated rules on all producers of a specific commodity. The rules are designed to overcome coordination problems that impair the marketability of the commodity. Typical rules include minimum quality standards, standardized packaging requirements, establishment of reserve pools for storable commodities, and regulation of the flow of product to market. Only producers of fruits, vegetables, milk, and specialty crops such as almonds are eligible to form marketing orders. The Agricultural Marketing Agreement Act of 1937 and its subsequent amendments give the secretary of agriculture the power to establish marketing orders. Without this authorization, many of the activities of marketing orders could be violations of antitrust law. "Federal marketing orders are locally administered by committees made up of growers and/or handlers, and often a member of the public. Marketing order regulations, initiated by industry and enforced by USDA, bind the entire industry in the geographical area regulated if approved by producers and the Secretary of Agriculture." U.S. Dep't of Agric., Fruit, Vegetable and Specialty Crop Marketing Orders, http://www.ams.usda.gov/AMSv1.0/ams.fetch TemplateData.do?more $=$ A.OptionalText 1 \& template $=$ TemplateA\&page $=$ FVMarket ingOrderLandingPage (last visited May 3, 2010).

241 See U.S. Food \& Drug Admin., Dep't of Health \& Human Servs., Quadrilateral Food Safety Group, http://www.fda.gov/InternationalPrograms/FDABeyond OurBordersForeignOffices/QuadtilateralandTrilateral/Quadrilateral/default.htm (last visited Nov. 3, 2009); see also New Zealand Food Safety Auth., NZFSA Profile (Dec. 2007), http://www.nzfsa.govt/nz/about-us/profile/december-2007/index.htm.

${ }^{242}$ Miranda Hitti, FDA Sets Fresh-Produce Safety Rules, WeBMD HEaLTH NEws, Mar. 12, 2007, http://www.webmd.com/food-recipes/food-poisoning/news/ 20070312/fda-sets-fresh-produce-safety-nules (describing some of the regulatory responses to such outbreaks). 
lized and larger scale, and have more direct impact on consumer safety pressure to regulate them is likely to increase. The United States already bans feeding offal to cattle and regulates pesticide use on farms and the nontreatment use of antibiotics. ${ }^{243}$ The FDA is currently developing proposed produce safety regulations, and the USDA is evaluating a proposed marketing agreement among fresh produce producers. ${ }^{244}$ Because each state has two senators, many rural, agricultural states have voting power in the Senate disproportionate to their population, and thus political resistance to a wholesale regulatory approach to the farm portion of farm-to-table food safety policy is likely to remain strong. Conventional wisdom has long held that on-farm safety rules in the U.S. were more likely to come in the form of selfimposed marketing orders among producers than formal government regulation. But the current FDA efforts at establishing produce safety regulation of farm production may open the way to more on-farm regulation.

One of the basic structural problems in U.S. food safety regulation is that responsibility is fragmented among as many as fifteen federal agencies, states and localities. ${ }^{245}$ Primary federal responsibilities are

${ }^{243}$ See 21 C.F.R. $\$ 589.1$ (2008). Pesticide use inconsistent with the labeling is prohibited under FIFRA. The Federal Insecticide, Fungicide, and Rodenticide Act (FIFRA) of 1996, 7 U.S.C. $\$ 136(j)(a)(1)(G)$ (2006); see Labeling Requirements for Pesticides and Devices 40 C.F.R. $\$ 156.10(\mathrm{i})(2)(2008)$. Similarly, FDA regulates drug use on a drug-by-drug basis. Use of antibiotics as feed additives is regulated by the drug label. See U.S. Food \& Drug Admin., Dep't of Health \& Human Servs., Antimicrobial Resistance, http://www.fda.gov/AnimalVeterinary/SafetyHealth/ AntimicrobialResistance/default.htm (last visited May 3, 2010). FDA also has an educational program on judicious use of antibiotics in feed aimed at preventing antibiotic resistance. U.S. Food \& Drug Admin., Dep't of Health \& Human Servs., Judicious Use of Antimicrobials, http://www.fda.gov/AnimalVeterinary/SafetyHealth/ AntimicrobialResistance/JudiciousUseofAntimicrobials/default.htm (last visited May 3,2010 ). Legislation has been proposed to strengthen restrictions on use of antibiotics in feed as growth promoters. See Preservation of Antibiotics for Medical Treatment Act of 2009, H.R. 1549, 111 th Cong. (2009), available at http://thomas .loc.gov/; Preservation of Antibiotics for Medical Treatment Act of 2009: Hearing on H.R. 1549 Before the H. Comm. on Rules, 111 th Congr. 8 (2009) (statement of Joshua M. Sharfstein, Principal Deputy Comm'r of Food \& Drugs, FDA); Chris Baltimore, Consumer Groups Point to Holes in Cattle Feed Rules, ReuTERS, Jan. 3, 2004, http://www.organicconsumers.org/madcow/feedrules $1304 . \mathrm{cfm}$.

${ }_{244}$ Preventive Controls for Fresh Produce; Request for Comments, 75 Fed. Reg. 8,086, 8,087 (Feb. 23, 2010); see also U.S. Food \& Drug Admin., USDA and FDA Coordinating Efforts to Assure Safe Product: FDA Invites Public Comments to Inform Future Rulemaking, http://www.fda.gov/NewsEvents/Newsroom/Press Announcements/ucm200965.htm (last visited May 3, 2010).

${ }^{245}$ See U.S. Gov't Accountability Office, Revamping Federal Oversight of Food Safety, http://www.gao.gov/highrisk/risks/safety-security/food_safety.php (last visited May 3, 2010). 
placed in four agencies: USDA (meat, poultry, and processed egg products), EPA (setting pesticide tolerances), Commerce (seafood), and FDA (all other foods including food additives and economic adulteration). ${ }^{246}$ The U.S. Centers for Disease Control and Prevention, together with state public health authorities, are responsible for disease surveillance. Local public health authorities and state offices of public health are jointly responsible for regulating food hygiene in local food service and retail establishments, assisted by FDA model food hygiene codes. As discussed above, similar fragmentation drove food safety reform in the United Kingdom and the European Union. For close to three decades, the General Accountability Office has argued for consolidation of federal food safety responsibilities into a single federal food safety agency. ${ }^{247}$ Despite a recent string of nationwide foodborne illness outbreaks and highly publicized failures of import controls, however, there does not appear to be the political will to consolidate. In part, recent difficulties with the formation of the Department of Homeland Security have raised questions about such consolidation. $^{248}$ Current legislative proposals focus on the more limited goal of strengthening FDA food safety authority. ${ }^{249}$

Discussion has been ongoing about the need for policy reform in the United States. After more than a decade of reports identifying the need for fundamental reform of the U.S. food safety system, the GAO placed the federal food safety system on the high-risk area designation list. $^{250}$ The Clinton, Bush, and Obama administrations have all convened senior working groups to develop plans for pushing forward with reforms. $^{251}$ At least in broad concepts, the reform agendas of

246 See U.S. Gov't AcCountability OfFICE, Oversight of FoOd SAFETy ACtivities: Federal Agencies Should Pursue Opportunities to Reduce OverlaP AND BETTER LEVERAGE RESOURCES 1-2 (2005), available at http:/www.gao.gov/new .items/d05213.pdf.

247 U.S. Gov't ACCOUNTABILITY OFFICE, FOOd SAFETY: SElected COUNTRIES' Systems CAN OFFER INSIGHTS INTO ENSURING IMPORT SAFETY AND RESPONDING TO FOODBORNE ILLNESS (2008), available at http://www.gao.gov/ new.items/d08794.pdf (citing over thirty years of GAO reports calling for substantial reform and consolidation of federal food safety agencies).

${ }^{248}$ Mimi Hall, Ex-Official Tells of Homeland Security Failures, USA TODAY, Dec. 27, 2004, available at http://www.usatoday.com/news/washington/ 2004-12-27-homeland-usat x.htm. (2009).

${ }^{249}$ See Food Safety Modernization Act of 2009, H.R. 875, 111 th Cong. $\S 2$

${ }^{250}$ U.S. Gov't ACCOUNTABILITY OfFICE, FEDERAL OVERSIGHT OF FoOd Safety: High-Risk Designation Can Bring NeEded attention to Fragmented SYSTEM (2007), available at http://www.gao.gov/new.items/d07449t.pdf.

251 See Comm. to Ensure Safe Food from Prod. to Consumption, Inst. of Med. \& Nat'l Research Council, Ensuring Safe Food: From Production to 
both administrations reflect the vision for a new generation of food safety policy that is emerging globally. This is not surprising, as the United States played a central role in the discussions that helped form this consensus. 252

On July 31,2009 , the U.S. House passed a bill that would make the first major changes to FDA authority since $1938 .^{253}$ The bill addresses only FDA reform. It does not update USDA's meat inspection statutory authority or address the issue of consolidating food safety authority into a single agency. The House bill would for the first time require all U.S. food establishments to register their operations. It would require all food establishments, not just egg, juice, and seafood establishments, to operate under HACCP plans. ${ }^{254}$ For the first time, compliance with the HACCP plan would be based on meeting performance standards. ${ }^{255}$ These provisions have farm-to-table coverage. $^{256}$ FDA inspection resources have eroded and the frequency with which the FDA inspects establishments has diminished over the past several decades. The House bill tries to promote more effective use of inspection resources by using risk criteria in determining FDA inspection frequency. ${ }^{257}$ The bill tries to improve containment of outbreaks by giving the FDA mandatory recall authority and imposing traceabil-

Consumption app. C (1997) (outlining a preventive, farm-to-table, science-based food safety system for the United States for Pres. Clinton). Under the Bush Administration, a high level interagency panel was convened to address import safety concerns. See Interagency Working Group on Import SafeTy, Dep'T of Health \& Human Servy. et al., Action Plan for Import Safety: A Roadmap for CONTINUAL IMPROVEMENT (2007), http://www.importsafety.gov/report/actionplan .pdf. The Obama administration made food safety an early initiative, forming a working group headed by the secretaries of agriculture and health and human services. The working group's key findings identify three core principles to guide food safety reform: preventing harm to consumers as a first priority; developing and using good data and analysis to guide inspection and enforcement activities; and ensuring rapid response to outbreaks through establishment of a traceback system. These principles echo international discussions about the elements of strong food safety governance systems. See President's Food Safety Working Group, Food Safety Working Group: KEY FindINGS, http://www.foodsafetyworkinggroup.gov/FSWG_Key Findings.pdf (last visited May 3, 2010); Jane Zhang, White House Aims to Toughen Food Safety, WALL ST. J., July 8, 2009, available at http://online.wsj.com/article/ SB124696814410505375.html (discussing administrative actions federal agencies are taking to improve food safety under the Obama administration).

${ }^{252}$ See Post, supra note 76.

${ }^{253}$ Food Safety Enhancement Act of 2009, H.R. 2749, 111 th Cong. (1st Sess. 2009).
${ }^{254} I d$. at $\$ \S 101,102$.
${ }^{255} I d$. at $\$ 103$.
256 Id. at $\$ 104$.
${ }^{257}$ Id. at $\S 105$. 
ity requirements on U.S. food establishments. ${ }^{258}$ It addresses import safety directly by requiring importers to ensure that their foreign suppliers meet U.S. standards. ${ }^{259}$ And it enhances the FDA's authority to enforce federal food safety law. ${ }^{260} \mathrm{~A}$ similar bill is currently pending before the Senate. ${ }^{261}$ The bill is facing substantial opposition from small-scale agricultural producers because of the provisions that extend regulation to farm production and a belief that the requirements would be impracticably burdensome on small-scale operators. ${ }^{262}$ These concerns point to the need to design policy that works not only for a wide range of firms, but also for diverse consumer desires. Whether the bill passes or not, its provisions, as well as the contents of food safety plans developed by interagency and presidential working groups, all point toward U.S. adoption of concepts at the core of the "new generation" of food safety policy emerging across the globe.

\section{CONCLUSION}

Despite recent campaigns for more localized food production, the reality is that for most people in the United States and other developed countries, their food supply is becoming more globalized. That globalization carries significant benefits for consumers. We are a long way from the 1920s, when children living in Iowa viewed a fresh orange in her Christmas stocking as a special treat. But globalization, along with changes in domestic food processing and production, clearly raises new challenges to ensuring the safety of the food supply.

The United States is operating under food safety statutes that remain in large part unchanged since their adoption in 1906. Responsibility for food safety regulation is spread among four major departments, all of which have other major missions in addition to food safety. But even in the absence of legislative reform, the United States has played a central role in the development of an international consensus on how to modernize food safety policy. This consensus is "enforced" by economic incentives such as the desire of multinational food firms to avoid disruption of business and liability and to protect their brand names and market shares. It is also "enforced" by the desire of national governments to promote their countries' exports. And

${ }^{258} I d$. at $\S \S 107,111$.

259 Id. at $\S 113$.

260 Id. at $\S \S 131-135$.

${ }^{261}$ Food Safety Modernization Act, S. 510, 11 th Cong. (1 st Sess. 2009).

${ }^{262}$ Leah Zerbe, Organic Food Threatened by Pending Food Legislation, RoDALE, Nov. 30, 2008, http://www.rodale.com/food-safety-legislation. 
ultimately, it is enforced by the threat of trade sanctions and by national law.

The lack of legislative reform in the United States has resulted in federal agencies attempting to modernize food safety regulation under the handicap of seriously outdated statutory authority. In the end, U.S. food safety policy is modernizing, but more slowly and less effectively than it could with updated statutory authority. This is a good moment for legislative reform in the United States, not only because the series of highly publicized failures over the past several years clearly demonstrates the need for change, but also because decades of work in this country and abroad have created a clear understanding of the kind of structure that is needed. At the same time, an independent mind needs to be brought to the adaptation of international guidance to U.S. conditions. Just as U.S. case law has been known to go astray in response to extreme facts, so too have domestic crises in other countries influenced their laws and their roles in international negotiations in ways that may not provide wise guidance for the United States. Lessons from comparative law must always be undertaken with a critical eye. 